\title{
The Biocontrol and Plant Growth- Promoting Properties of Streptomyces alfalfae XN-04 Revealed by Functional and Genomic Analysis
}

\author{
Jing Chen, Lifang Hu, Na Chen, Ruimin Jia, Qing Ma and Yang Wang* \\ College of Plant Protection, Northwest A\&F University, Yangling, China
}

Fusarium wilt of cotton, caused by the pathogenic fungal Fusarium oxysporum f. sp. vasinfectum (Fov), is a devastating disease of cotton, dramatically affecting cotton production and quality. With the increase of pathogen resistance, controlling Fusarium wilt disease has become a significant challenge. Biocontrol agents (BCAs) can be used as an additional solution to traditional crop breeding and chemical control. In this study, an actinomycete with high inhibitory activity against Fov was isolated from rhizosphere soil and identified as Streptomyces alfalfae based on phylogenetic analyses. Next, an integrative approach combining genome mining and metabolites detection was applied to decipher the significant biocontrol and plant growth-promoting properties of $\mathrm{XN}-\mathrm{O} 4$. Bioinformatic analysis and bioassays revealed that the antagonistic activity of $\mathrm{XN}-04$ against Fov was associated with the production of various extracellular hydrolytic enzymes and diffusible antifungal metabolites. Genome analysis revealed that XN-04 harbors 34 secondary metabolite biosynthesis gene clusters. The ability of XN-04 to promote plant growth was correlated with an extensive set of genes involved in indoleacetic acid biosynthesis, 1-aminocyclopropane-1-carboxylic acid deaminase activity, phosphate solubilization, and iron metabolism. Colonization experiments indicated that EGFP-labeled $\mathrm{XN}-\mathrm{O} 4$ had accumulated on the maturation zones of cotton roots. These results suggest that $\mathrm{S}$. alfalfae $\mathrm{XN}-04$ could be a multifunctional BCA and biofertilizer used in agriculture.

Keywords: Fusarium oxysporum f. sp. vasinfectum, Streptomyces alfalfae, antifungal, plant growth-promoting, genome

\section{INTRODUCTION}

Fusarium wilt of cotton, caused by the pathogen Fusarium oxysporum f. sp. vasinfectum (Fov) W.C. Synder and H.N. Hans, has led to severe losses in yield and quality in most cottongrowing areas of the world (Guo et al., 2015). The hyphae of Fov reside in the woody vascular tissues and produce chlamydospores which are able to persist in soil for over 10 years (Cox et al., 2019). Therefore, it is quite difficult to control Fusarium wilt of cotton. The current strategies for the management of Fusarium wilt include breeding disease-resistant varieties, 
seed and soil disinfection, rotation, and chemical control (Cianchetta and Davis, 2015). In fact, Fusarium wilt management relies mainly on synthetic antifungal agents (e.g., carbendazim and azoxystrobin). Although chemical fungicide treatment shows some reduction of Fusarium wilt, the long-term overuse of fungicides has been reported to produce plenty of adverse effects, e.g., serious environmental pollution, threats to animal and human health, poor soil quality, and pathogens resistance to fungicide (Raza et al., 2017). Consequently, it is important to develop alternative methods and agents which have low toxicity and are more environmentally friendly in efficient control of Fusarium wilt. Among the alternatives, biological control may be one of the few options that show potential (Chen et al., 2018).

A number of biocontrol agents (BCAs), such as Trichoderma spp. (Nieto-Jacobo et al., 2017; Hewedy et al., 2020; Diaz-Gutierrez et al., 2021), Penicillium spp. (Li et al., 2019), nonpathogenic Fusarium spp. (Zhang et al., 2018b), Bacillus spp. (Luo et al., 2019), Pseudomonas spp. (Fatima and Anjum, 2017; Yu et al., 2017), and Streptomyces spp. (Abbasi et al., 2019; Heinsch et al., 2019; Peng et al., 2020), have been investigated to control Fusarium wilt. These BCAs employ a variety of strategies to control plant disease by both direct and indirect mechanisms. The most extensive studies on the mechanisms of biocontrol have focused on antibiosis. For example, Streptomyces rimosus M527 secretes the macrolides antibiotic, rimocidin, which inhibits fungal growth by interacting with cell membranes through ergosterol-forming channels (Song et al., 2020). A biocontrol strain of the Grampositive bacterium Bacillus amyloliquefaciens SQR9 secretes the lipopeptide antibiotic bacillomycin D when SQR9 is confronted with Fusarium oxysporum (Li et al., 2014). In addition, the modes of action of disease suppression include competition for space, nutrients, or microelements, as well as degrading fungal virulence factors or priming of plant immunity (Chen et al., 2018).

Out of all BCAs, some species from the Streptomyces genus are regarded to be special in controlling plant disease because they exhibit many excellent traits. Streptomyces species are aerobic, Gram-positive, and spore-forming actinomycetes, which have a linear chromosome and several plasmids in a linear or circular form. They have relatively large genomes, approximately $8 \mathrm{Mb}$ to $10 \mathrm{Mb}$ in size depending on the specific species, and with high $\mathrm{G}+\mathrm{C}$ content (69-73\%; Hwang et al., 2014). One of the unique features of the genome of the Streptomyces species is the presence of biosynthetic gene clusters (BGCs) which encode enzymes contributing to the production of substantial secondary metabolites with multiple biological activities (Baltz, 2016). Genomic data have shown that Streptomyces spp. have the potential to produce even more secondary metabolites than have been isolated from them to date, as a large number of BGCs have been revealed (Lee et al., 2020). Consequently, the systematic investigation of Streptomyces species at the genetic level is becoming more important for counteracting pathogens. More importantly, their filaments and ability to sporulate help them cleave strongly to the rhizospheric soil particles forming a strong bond with the plants (Olanrewaju and Babalola, 2019). These traits are considered to be very useful in biological control of plant diseases.

In recent years, rapid development of high-throughput sequencing technology has provided new tools that are actively applied to study BCAs (Choi et al., 2015). Many BCAs are more deeply studied using genomics, and their metabolites are widely characterized using gas chromatography-mass spectrometry (GC-MS) and liquid chromatography-mass spectrometry technologies, which are providing new insights into their metabolism, biochemical properties, and potential for production of secondary metabolites (Pan et al., 2019). Previous study reported that a total of 21 different compounds identified from Streptomyces sp. SCA3-4 by GC-MS were composed of phenolic compound, pyrrolizidine, hydrocarbons, esters, and acids (Qi et al., 2019). S. alfalfae was originally described in 2016 and has already been used for fungal disease control (She et al., 2016). However, the mechanisms of $S$. alfalfae for promoting plant growth and inhibiting fungal pathogens remain to be elucidated. Elucidation of the biocontrol mechanisms of $S$. alfalfae at genomic level is necessary for the efficient application of such plant-beneficial microorganisms in agriculture.

In this study, we obtain a potential BCA, S. alfalfae XN-04, which displayed plant growth-promoting activity and a strong antagonistic activity against Fov. To better understand the mechanisms underlying the diverse and beneficial biological activities of this strain, we assessed the following objectives: (1) evaluate the biocontrol efficacy of $\mathrm{XN}-04$ under greenhouse conditions, (2) evaluate the effect of $\mathrm{XN}-04$ on cotton growth, (3) a comprehensive genome sequence analysis of XN-04, (4) characterize the metabolites produced by XN-04, and (5) evaluate the colonization ability of $\mathrm{XN}-04$ in cotton roots, and all these information provided essential insights into the biocontrol properties of $S$. alfalfae XN-04.

\section{MATERIALS AND METHODS}

\section{Sample Collection and Isolation of Actinomycetes}

The rhizosphere soil samples used in this study were collected in a cucumber commercial greenhouse $\left(36^{\circ} 49^{\prime} 16^{\prime \prime} \mathrm{N}\right.$, $101^{\circ} 36^{\prime} 43^{\prime \prime} \mathrm{E}$; Xining City, Qinghai Province, China) and a commercial cabbage field $\left(33^{\circ} 24^{\prime} 26^{\prime \prime} \mathrm{N}, 104^{\circ} 56^{\prime} 48^{\prime \prime} \mathrm{E}\right.$; Longnan City, Gansu Province, China), respectively. The greenhouse has grown tomatoes and cucumbers over 5 years and suffered from Fusarium wilt for more than 2 years. The field has grown cabbage for more than 10 years, and Fusarium wilt has occurred since 2009. A total of 10 healthy cucumber plants along with the rhizosphere soil $(\mathrm{pH}=7.6-7.8)$ were collected in May, 2016. Similarly, 10 healthy cabbage plants along with the rhizosphere soil ( $\mathrm{pH}=7.5-7.6)$ were collected in June, 2016. The roots of plants were removed from the soil and the bulk soil was shaken off gently. All samples were placed in sterile plastic bags, subsequently transferred to the laboratory and air-dried for 3 days.

Rhizosphere actinomycetes were isolated using dilution plating method (Awla et al., 2017). Briefly, the dried root samples 
( $1 \mathrm{~g}$ rhizosphere soil attached) were suspended in $100 \mathrm{ml}$ sterile double-distilled water $\left(\mathrm{ddH}_{2} \mathrm{O}\right)$ with glass beads, incubated in an incubator shaker at $180 \mathrm{RPM}$ at $28^{\circ} \mathrm{C}$ for $30 \mathrm{~min}$, and finally filtered with a double-layer gauze to obtain the rhizosphere soil suspension. Subsequently, $100 \mu \mathrm{l}$ of the dilution sample was placed on the surface of Gauze's synthetic no. 1 (GS) medium that was supplemented with filter-sterilized potassium dichromate $\left(5 \times 10^{-6} \mathrm{~g} / \mathrm{l}\right)$. The plates were incubated at $28^{\circ} \mathrm{C}$ for 10 days. Colonies of actinomycetes on the agar plates were picked on the basis of their growth rate, colony size, and morphological characteristics. Pure cultures were obtained by re-growth on GS medium and preserved as spore suspensions in $20 \%$ glycerol at $-80^{\circ} \mathrm{C}$ freezer.

\section{Antifungal Activity Assay in vitro}

A total of 13 phytopathogenic fungi were preserved in the Biological Control of Plant Disease Laboratory of Northwest Agriculture and Forestry University and were grown in Potato Dextrose Agar (PDA) plates at $28^{\circ} \mathrm{C}$ for 5 days. All isolated actinomycetes were used for exploring antifungal activity as previously described with slightly modifications (Suarez-Moreno et al., 2019). Four wells (6 $\mathrm{mm}$ diameter) were evenly perforated forming a cross around the center ( $25 \mathrm{~mm}$ from center), and $100 \mu \mathrm{l}$ of each actinomycetes cell suspension $\left(10^{8} \mathrm{cfu} / \mathrm{ml}\right)$ was poured into the relative two wells. A negative control consisted of using the other two wells injected with the same amount of GS broth. A mycelial plug of $6 \mathrm{~mm}$ diameter from the edge of every 5 days old fungus was cut and transferred into the center of the actinomycetes-pregrown PDA plate. Petri dishes were incubated at $28^{\circ} \mathrm{C}$ for 7 days, and the inhibition radius was measured. Each treatment had three plates, and the experiment was repeated three times.

\section{Evaluation of Biocontrol Efficiency}

The biocontrol efficacy of XN-04 against Fov in a growth chamber was determined using the cotton cultivar Jimian 11 (susceptible to Fov) and the protocols described previously (Chen et al., 1995). Cotton seeds were surface sterilized with $4 \%$ sodium hypochlorite for $5 \mathrm{~min}$ and rinsed three times in sterile distilled water $(\mathrm{SDW})$. Culture pots $(13 \mathrm{~cm}$ high $\times 11 \mathrm{~cm}$ diameter) were filled with sterilized soil and $25 \mathrm{ml}$ of the different concentrations $\left(10^{6} \sim 10^{9} \mathrm{cfu} / \mathrm{ml}\right)$ of $\mathrm{XN}-04$ cell suspensions was added to the soil of each pot. Pathogen inoculation was performed 7 days post-actinomycetes treatment by watering each plant with $25 \mathrm{ml}$ of the conidial suspension of Fov $\left(10^{8}\right.$ conidia $\left./ \mathrm{ml}\right)$. A negative control was performed using uninoculated control seedlings treated with SDW only, while the positive control was inoculated with Fov and treated with SDW. In addition, carbendazim treatment was used as the chemical control.

All cotton plants were grown in a growth chamber at $23^{\circ} \mathrm{C}$ and $16 \mathrm{~h}$ photoperiod, and watered with SDW every 3 days. Two weeks after inoculation with Fov, all parameters were evaluated. Disease severity ratings were determined using a $0-4$ rating scale ( 0 , no symptoms; $1,1-25 \%$ of leaves with symptoms; 2, 26-50\% of leaves with symptoms; $3,51-75 \%$ of leaves with symptoms; and 4, 76-100\% of leaves with symptoms).
Each treatment had 15 cotton plants, and the experiment was repeated three times.

Disease index and biocontrol efficiency were calculated as follows:

$$
\begin{aligned}
& \text { Disease index }=\frac{\sum\left(\begin{array}{l}
\text { number of diseased plants of } \\
\text { each grade } \times \text { value of relative grade }
\end{array}\right)}{\text { total number of investigated plants } \times 4} \times 100 \\
& \text { disease index of control group - } \\
& \text { Control efficiency }=\frac{\text { disease index of treatment group }}{\text { disease index of control group }} \times 100 \%
\end{aligned}
$$

\section{Plant Growth-Promoting Experiments}

In each treatment, a total of 100 cotton seeds were fully submerged in $100 \mathrm{ml} \mathrm{XN-04} \mathrm{cell} \mathrm{suspensions}\left(10^{6} \sim 10^{9} \mathrm{cfu} / \mathrm{ml}\right)$ for $12 \mathrm{~h}$. The treated seeds were placed into a plug tray $(53 \times 27 \times 4 \mathrm{~cm}$ deep $)$ filled with sterilized soil, with one seedling occupying each cell. The seeds submerged in SDW were used as the negative control. The biometric properties (plant height, root length, fresh weight, and dry weight) were measured at the 20th days after seed sowing. This experiment was repeated three times.

\section{Genome Sequencing, Assembly, Annotation, and Bioinformatics Analysis DNA Extraction}

The genomic DNA of XN-04 was extracted using a Wizard ${ }^{\circledR}$ Genomic DNA Purification Kit (Promega) according to the manufacturer's protocol. Purified genomic DNA was quantified by the TBS-380 fluorometer (Turner BioSystems, Sunnyvale, CA). High-quality DNA (OD260/280=1.8 2.0, > $20 \mu \mathrm{g}$ ) was used to conduct the further research.

\section{Sequencing, Assembly, and Annotation}

The whole genome of $\mathrm{XN}-04$ was sequenced using a combined strategy of Illumina PE platform and PacBio RS II Single Molecule Real Time (Majorbio Bio-pharm Technology Co., Ltd., Shanghai, China). The reads were de novo assembled using both canu version 1.4 (Koren et al., 2017) and SPAdes version 3.8.2 (Bankevich et al., 2012). The protein-coding genes (CDSs) prediction was carried out using Glimmer version 3.02 (Delcher et al., 2007). The rRNA and tRNA were analyzed using Barrnap version 0.8 (Seemann and Booth, 2018) and tRNA-scan-SE version 2.0 (Lowe and Eddy, 1997), respectively. Gene annotation was carried out in BLAST searches of widely used databases, i.e., NCBI non-redundant (NR), Swiss-Prot (Apweiler et al., 2004), Pfam (Finn et al., 2014), Clusters of Orthologous Groups (COG; Jensen et al., 2008), Gene Ontology (GO; Ashburner et al., 2000), and Kyoto Encyclopedia of Genes and Genomes (KEGG; Kanehisa and Goto, 2000) databases. The circular graphical representation of chromosome and plasmid was analyzed using a comparative genomics tool CGView 2.0 (Stothard and Wishart, 2005). Carbohydrate-active enzymes were annotated according to the Carbohydrate-Active enZYmes (CAZy) database using the dbCAN2 meta server (Zhang et al., 2018a). In addition, the antibiotic and secondary metabolite 
production gene clusters were examined using the program antiSMASH version 6.0 (Blin et al., 2021).

\section{Identification and Characterizations of $\mathrm{XN}-04$}

\section{Phylogenetic Analyses}

The 16S rRNA gene sequences were used as queries in BLAST searches through the NCBI GenBank nucleotide database. Multiple alignments of $16 \mathrm{~S}$ rRNA gene sequences and 31 housekeeping gene sequences were conducted using the program Clustal X, respectively (Larkin et al., 2007). The phylogenic tree was constructed using the neighbor-joining method with the program MEGA version 7.0 (Center for Evolutionary Functional Genomics, United States; Kumar et al., 2016).

\section{Cultural and Morphological Characterizations}

Morphological characteristics of $\mathrm{XN}-04$, including spore size and surface ornamentation, were observed by scanning electron microscopy (SEM; Hitachi model S-3400 N, Japan) of 14 day old cultures grown on MS medium. The cultural characteristics of $\mathrm{XN}-04$, including color of spore mass, aerial mycelium, substrate mycelium, and diffusible pigments, were recorded after incubation at $28^{\circ} \mathrm{C}$ for 14 days on ISP, PDA, GS, and mannitol soybean (MS) medium, respectively.

\section{Strain Characterizations}

The utilization of sole carbon and nitrogen sources was tested as previously described (Williams et al., 1983). Other biochemical characteristics tests were carried out according to Bergey's Manual of Systematic Bacteriology (Holt et al., 1994). The temperature sensitivity for growth was determined from $5^{\circ} \mathrm{C}$ to $50^{\circ} \mathrm{C}$ at intervals of $5^{\circ} \mathrm{C}$ on Bennett medium after incubation for 7 days. The $\mathrm{NaCl}$ tolerance $[0-10 \%(\mathrm{M} / \mathrm{V})$ in $1 \%$ intervals] was evaluated after XN-04 growth on Bennett medium at $28^{\circ} \mathrm{C}$ for 7 days. In addition, $\mathrm{XN}-04$ was characterized for its ability to produce extracellular enzymes (i.e., chitinase, cellulolytic, $\beta$-1, 3-glucanase, protease, and lipase), indoleacetic acid (IAA), 1-aminocyclopropane-1-carboxylic acid (ACC) deaminase, siderophores, $\mathrm{HCN}$, and phosphate solubilization as described elsewhere (Jang and Chen, 2003; Nascimento et al., 2020).

\section{Antifungal Activity of XN-04 Extract Production and Extraction of Antifungal Metabolites}

The strain XN-04 was cultured in GS broth at 180 RPM at $28^{\circ} \mathrm{C}$ for 14 days. A total of 101 fermentation broth was centrifuged at $5000 \mathrm{RPM}$ at $4^{\circ} \mathrm{C}$ for $10 \mathrm{~min}$ to pellet cells and to generate a cell-free supernatant. The cell-free supernatant was evaporated to dryness using a rotary vacuum evaporator under reduced pressure at $50^{\circ} \mathrm{C}$. The mycelia were extracted with methanol $(\mathrm{MeOH})$ and then concentrated in vacuo. Subsequently, four solvents of different polarity, i.e., petroleum ether (PE), dichloromethane (DCM), ethyl acetate (EtOAc), and n-butanol, were used to extract antifungal metabolites from the $\mathrm{MeOH}$ extract, respectively. All organic solvent extracts were concentrated to $50 \mathrm{mg} / \mathrm{ml}$. Antifungal activity was evaluated with concentrations of $50 \mu \mathrm{g} / \mathrm{ml}$ using the method as described by Mei et al. (2019).

\section{TLC Analysis}

The EtOAc extract $(10 \mathrm{mg} / \mathrm{ml})$ was analyzed by Thin layer chromatography (TLC) using DCM: $\mathrm{MeOH}(6: 1, \mathrm{v} / \mathrm{v})$ as solvent system. The developed TLC plates were air-dried to remove all traces of solvents and visualized under ultra-violet (UV) at $254 \mathrm{~nm}$ (absorbance) and stained with iodine. To further analyze the number of active antifungal metabolites in the EtOAc extract, TLC chromatogram strips were placed on the surface of PDA plates containing Fov spores. Plates were incubated at $28^{\circ} \mathrm{C}$ for 3 days. The number of antifungal metabolites in the EtOAc extract was determined by observing clear zones using Retardation factor (Rf) values.

\section{Stability of Antifungal Metabolites}

To examine the effect of temperature, the EtOAc extract was incubated at $20,40,60,80,100$, and $121^{\circ} \mathrm{C}$ for $1 \mathrm{~h}$, respectively. After the sample was cooled to room temperature, the antifungal activity was tested. For the $\mathrm{pH}$ test, $\mathrm{HCl}$ and $\mathrm{NaOH}$ solutions were used to adjust the EtOAc extract $\mathrm{pH}$ from 1.0 to 10.0 at intervals of 1.0. Afterward, the $\mathrm{pH}$ values were readjusted to 7.0, and the residual antifungal activity was tested. For the proteinase $K$ test, EtOAc extract was treated with $0.1 \mathrm{mg} / \mathrm{ml}$ of proteinase $\mathrm{K}$ at $37^{\circ} \mathrm{C}$ for $60 \mathrm{~min}$. Also, the EtOAc extract was exposed to sunlight for 12-96h and exposed to UV light for $0-4 \mathrm{~h}$ to check photostability, respectively. The antifungal activities were evaluated using the method described above. All experiments were performed in triplicate.

\section{GC-MS Analysis}

GC-MS was used to identify the chemical compounds in the extract of XN-04. Briefly, GC-MS was performed on a Shimadzu GC-2030 with a triple quadrupole mass spectrometer (TQ-8050 $\mathrm{NX}$ ). Helium as a carrier gas was injected at $1 \mathrm{ml} / \mathrm{min}$. The column temperature was programmed initially at $60^{\circ} \mathrm{C}$ for $1 \mathrm{~min}$, increased to $100^{\circ} \mathrm{C}$ at $5^{\circ} \mathrm{C} / \mathrm{min}$ for $5 \mathrm{~min}$, raised at $10^{\circ} \mathrm{C} / \mathrm{min}$ to $250^{\circ} \mathrm{C}$ for $35 \mathrm{~min}$, and finally kept to $280^{\circ} \mathrm{C}$ at $10^{\circ} \mathrm{C} / \mathrm{min}$ for $25 \mathrm{~min}$. The mass spectrometer was operated in electron ionization (EI) mode at $70 \mathrm{eV}$, with an interface temperature of $280^{\circ} \mathrm{C}$, an ion source temperature of $240^{\circ} \mathrm{C}$, a mass spectrometer acquisition delay time of $3.5 \mathrm{~min}$, and a continuous scan from 50 to $650 \mathrm{amu}$. Peaks were identified in comparison with the mass spectra data against the National Institute of the Standards and Technology (NIST) spectral library.

\section{Transformation and Colonization of XN-04} Creation of the Strain XN-04 Labeled With EGFP Escherichia coli strain ET12567 (harboring the helper plasmid pUZ8002) and plasmid pIJ8641 (carrying the EGFP gene under the constitutive ermE promoter) were preserved in the Biological Control of Plant Disease Laboratory. Plasmid pIJ8641 was transformed into the donor strain E. coli ET12567 (pUZ8002) and then conjugated into recipient $\mathrm{XN}-04$ as previously described (Kieser et al., 2000; Zhang et al., 2021). Genomic DNA of 
wild-type (WT-) and transformed (t-) XN-04 was extracted, and the quality was tested by primers $27 \mathrm{~F}$ ( $5^{\prime}$-AGAGT TTGAT CCTGG CTCAG-3') and 1492R (5'-GGTTA CCTTG TTACG ACTT-3'; Huang et al., 2020). The EGFP gene was detected in the $\mathrm{t}-\mathrm{XN}-04$ strain following the protocol described before (Bonaldi et al., 2015) and the expression was observed by Confocal Laser Scanning Microscope (CLSM; Olympus model FV3000, Japan). The t-XN-04 growth rate, mycelium morphology, and inhibiting effect against Fov were examined and compared to WT-XN-04.

\section{Colonization of Cotton Seedlings by EGFP-Labeled XN-04}

Cotton seeds (Jimian 11) were surface sterilized as described above. Surface-sterilized seeds were pre-germinated on filter paper at $28^{\circ} \mathrm{C}$ for 2 days. The germinated seeds were placed into plug tray $(53 \times 27 \times 4 \mathrm{~cm}$ deep) filled with sterilized soil, with one seeds occupying each cell. All cotton seedlings incubated in a growth chamber at $23^{\circ} \mathrm{C}$ with a $16 \mathrm{~h}$ photoperiod. After 7 days of incubation, $1 \mathrm{ml}$ EGFP-labeled XN-04 cell suspensions $\left(10^{8} \mathrm{cfu} / \mathrm{ml}\right)$ were uniformly distributed in every cell. The seedlings treated with SDW were used as negative control.

The colonization ability of EGFP-labeled XN-04 in the cotton rhizosphere was quantified and observed at 2, 4, and 7 days after inoculation. In general, cotton seedlings were carefully removed from the soil, and large soil aggregates were removed by gently shaking the plants. For plating count assay, the complete root parts were suspended in $10 \mathrm{ml}$ sterile $\mathrm{ddH}_{2} \mathrm{O}$ and vortexed for $10 \mathrm{~min}$. Then, the suspension was serially diluted with sterile $\mathrm{ddH}_{2} \mathrm{O}$, and $100 \mu \mathrm{l}$ cell suspension from various dilutions $\left(10^{-2}\right.$, $10^{-3}$, or $10^{-4}$ ) was plated into GS plates supplemented with apramycin $(50 \mu \mathrm{g} / \mathrm{ml})$. Plates were incubated at $28^{\circ} \mathrm{C}$ for 7 days, and the number of colony forming unites was determined. The colonization density of the EGFP-labeled XN-04 in rhizosphere was expressed as cfu/g of roots weight. The experiment was repeated three times with 10 root samples per replicate.

For CLSM observation, the roots were cut into $2 \mathrm{~cm}$ lengths, placed on microscope slides, and visualized using CLSM at an excitation wavelength of $488 \mathrm{~nm}$. All experiments were repeated using 10 roots, and representative results are shown.

\section{Statistical Analysis}

Statistical analysis, one-way ANOVA, and Duncan's multiple range test were performed using the software SPSS 24.0 (Chicago, IL, United States) in this study.

\section{RESULTS}

\section{Antagonistic Activity of XN-04 Against Fov in vitro and in Planta}

A total of 32 morphologically different actinomycetes (numbered GS-01 to GS-10 and XN-01 to XN-22) were isolated from the rhizosphere soil collected in Gansu and Qinghai Provinces, China. Among them, 16 actinomycetes exhibited various degrees of inhibitory activities against Fov (Supplementary Table S1). Notably, an actinomycete isolate (termed XN-04) demonstrated strong inhibitory activity against Fov during co-cultivation, producing a radius of inhibition zone $>13 \mathrm{~mm}$, and an inhibition zone $>10 \mathrm{~mm}$ against several other fungal pathogens (Figure 1A). To determine whether $\mathrm{XN}-04$ inhibited the growth of Fov in planta, we further conducted biocontrol experiments under greenhouse settings. Similar to Carbendazim $^{\circledR}$, a fungicide widely used to control Fov in China, treatment with $\mathrm{XN}-04$ at the optimum concentration $\left(10^{8} \mathrm{cfu} / \mathrm{ml}\right)$ by soil inoculation significantly $(p<0.05)$ reduced the wilt incidence and disease index (Figures 1B,C). These results indicate that $\mathrm{XN}-04$ is an effective BCA for the control of Fusarium wilt of cotton.

\section{Plant Growth-Promoting Activity of XN-04}

To determine the effect of $\mathrm{XN}-04$ on the growth of cotton seedlings, plants were harvested and all plant growth parameters were assessed at the 20th day after seed sowing. As shown in Figure 2A, the plant growth-promoting effect increased with the increased concentration of $\mathrm{XN}-04$ and then declined at a high concentration. The optimal effect was observed at a concentration of $10^{8} \mathrm{cfu} / \mathrm{ml}$. When compared to the non-inoculated control, values of shoot length, root length, fresh weight, and dry weight of the cotton seedlings inoculated with $\mathrm{XN}-04$ cell suspension (at $10^{8} \mathrm{cfu} / \mathrm{ml}$ ) were increased by 62.52, 81.56, 95.69, and 117.43\%, respectively (Figures 2A,B).

\section{Identification and Characteristics of $\mathrm{XN}-04$}

To characterize $\mathrm{XN}-04$, the isolate was grown in the standard medium described in the International Streptomyces Project (ISP) and micromorphology of sporulation was examined by SEM. XN-04 exhibited good growth on ISP 3, MS and PDA medium, and moderate growth on the other tested organic and synthetic medium. Moreover, XN-04 did not produce any water-diffusible pigments in any tested medium. For sporulation, different spore masses were yielded on different agar plates, with the largest number of spores obtained on MS medium followed by the spore yields on ISP 3 and PDA medium, sequentially. The detailed cultural characteristics of XN-04 are shown in Supplementary Table S2. The colony morphology of XN-04 showed a hard surface with white aerial mycelia and light pink spores (Figure 3A). Morphological observation of the 2 weeks culture of $\mathrm{XN}-04$ grown on MS medium revealed that it had typical morphological properties of the genus Streptomyces. Aerial and substrate mycelia were well developed without fragmentation. Sporulation in XN-04 featured cylindrical spores forming a flexuous spore chain with a rough surface (Figure 3B). Biochemical tests indicated that XN-04 was able to utilize almost all the tested carbon and nitrogen sources except for mannitol. $\mathrm{XN}-04$ was found to grow at a temperature range of 5 to $35^{\circ} \mathrm{C}$ and $\mathrm{NaCl}$ tolerance of 0 to $8 \%$ (optimum $\mathrm{NaCl}$ of 1 to $2 \%$ ). The other physiological and biochemical properties of XN-04 are given in Supplementary Table S3.

The XN-04 16S ribosomal RNA genes have six copies. A BLAST analysis of the complete $16 \mathrm{~S}$ rRNA gene sequences revealed that XN-04 was closely related to S. alfalfae ACCC40021 with $100 \%$ similarity. Next, phylogenomic trees were constructed based on the 16S rRNA gene and 31 house-keeping genes sequences using the neighbor-joining methods, respectively. 


\section{A}

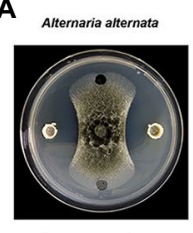

F. oxysporumf. sp.
vasinfectum
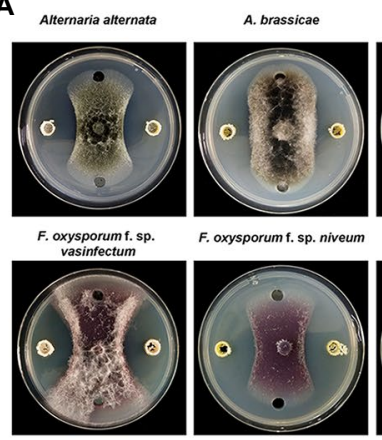

F. oxysporum f. sp. niveum

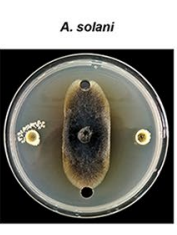

F. graminearum
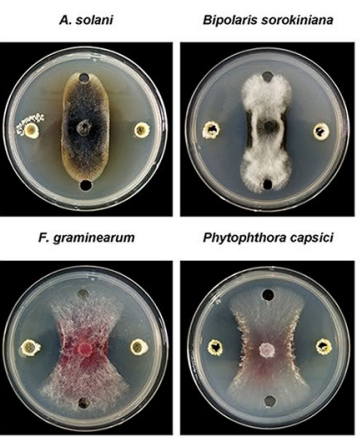

Phytophthora capsici
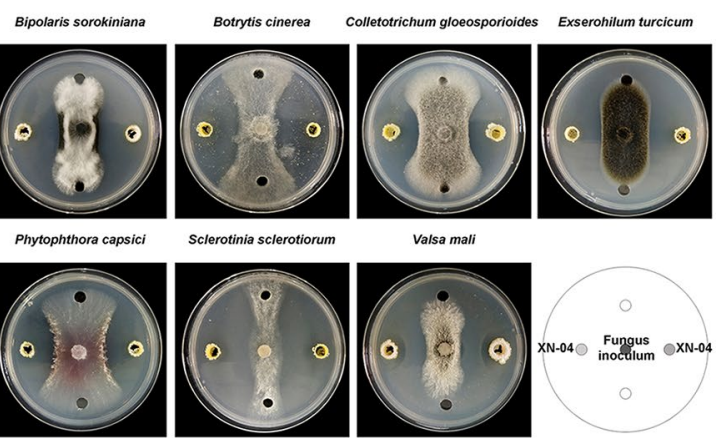

sclerotinia sclerotiorum

Valsa mall
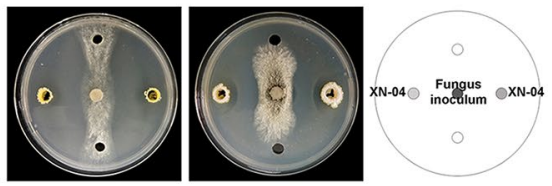

B

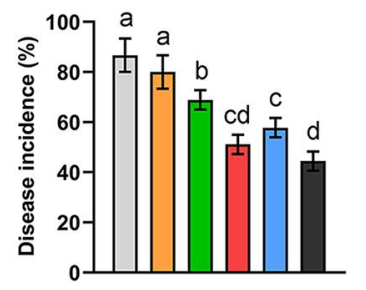

Treatments

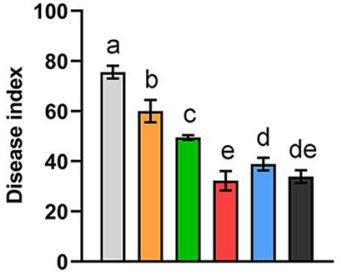

Treatments

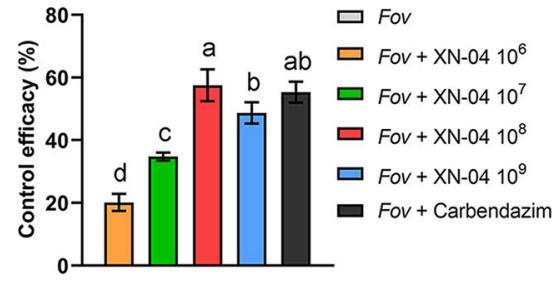

Treatments

C

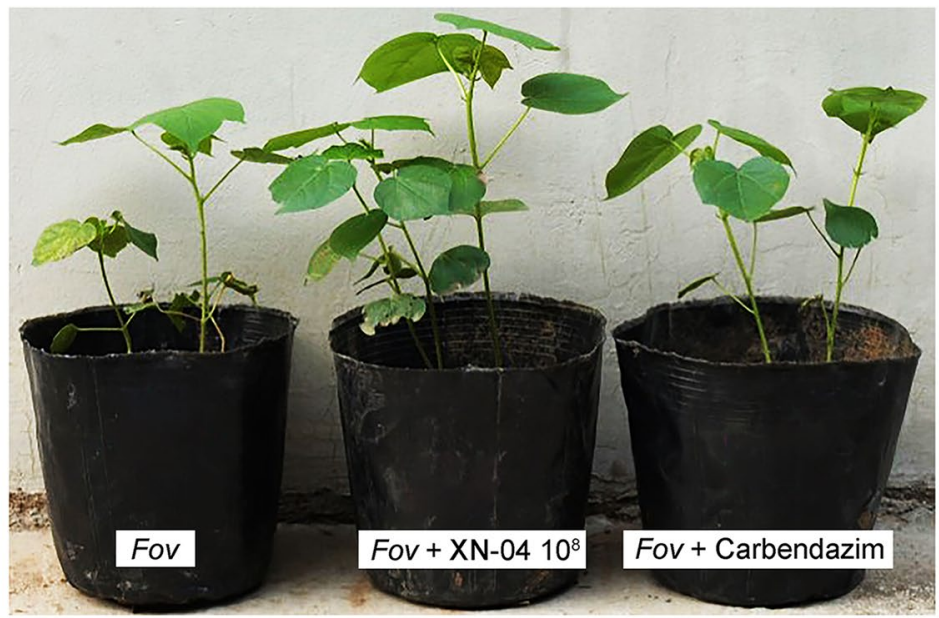

FIGURE 1 | The antifungal activity of XN-04. (A) Antagonistic activity of XN-04 against 13 important phytopathogenic fungi; (B) biocontrol efficacy of XN-04 against Fov under greenhouse conditions; and $(\mathbf{C})$ the symptoms of Fusarium wilt disease development on cotton in each treatment in greenhouse experiment. Data are mean $\pm \mathrm{SD}(n=5)$. Different lowercase letters indicate a significant difference at $p<0.05$ level by Duncan's new multiple range test.

XN-04 was grouped together with S. alfalfae ACCC40021 with a high bootstrap value (100; Figure 3C and Supplementary Figure 1). Altogether, $\mathrm{XN}-04$ is recognized as a new member of the $S$. alfalfae species.

\section{Genome Features of XN-04}

In order to fully understand the molecular mechanisms of plant growth-promoting and antagonism, the genome of XN-04 was sequenced. The complete genome of $\mathrm{XN}-04$ consists of an $8,254,035$ bp linear chromosome (Figure 4A) and a 24,560 bp circular plasmid (Figure 4B), with average GC content of $72.06 \%$ (Table 1). The complete chromosome and plasmid sequences for XN-04 have been deposited in the GenBank database with accession numbers CP060742 and CP060743, respectively. Analysis of the genome revealed that it contained 7,579 CDSs which account for approximately $88.36 \%$ of the genome.

Functional analysis by COG, GO, and KEGG revealed that $5,657,4,976$, and 2,726 out of the 7,579 identified CDSs were assigned to COG, GO, and KEGG categories, respectively. These 7,579 CDSs could be assigned to four broadly functional categories by COG analysis. The predicted proteins associated with metabolism were the most abundant type (40.78\%), followed by poorly characterized $(38.18 \%)$, information storage and 
A

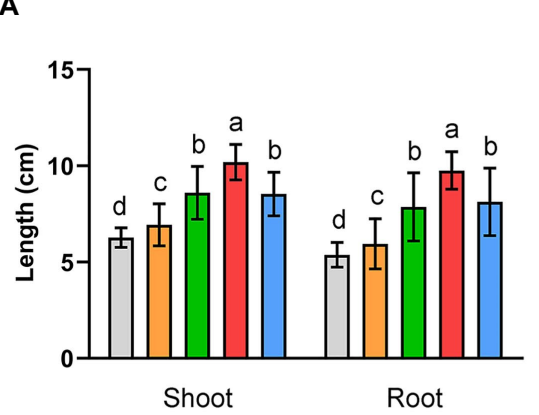

B

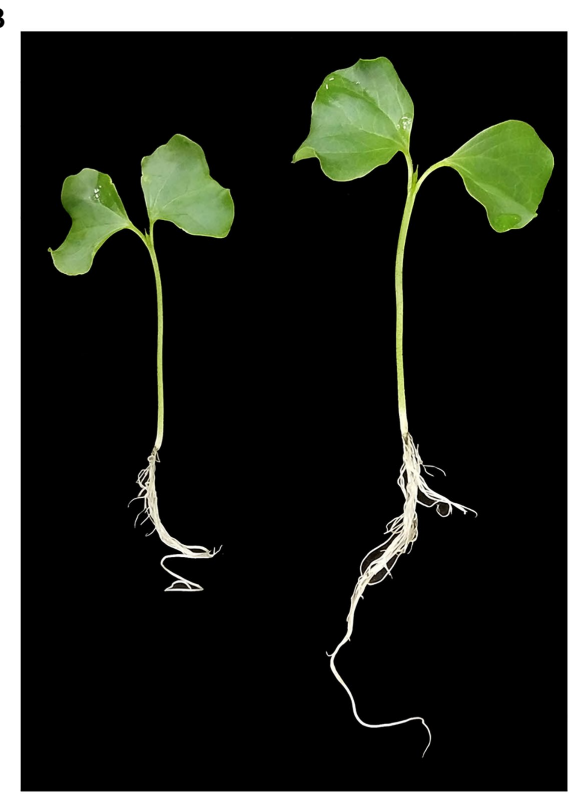

FIGURE 2 | Cotton plants growth-promoting assay. (A) Data for shoot length, root length, fresh weight, and dry weight of cotton plants 14 days after XN-04 inoculation. Data are mean \pm SD $(n=5)$. Different lowercase letters indicate a significant difference at $p<0.05$ level by Duncan's new multiple range test. (B) Overall plant development.

processing (19.53\%), and cellular processes and signaling (16.76\%; Supplementary Figure 2). To explain the relevance of the genome of $\mathrm{XN}-04, \mathrm{GO}$ analysis was used to categorize genes into three categories according to matching with known sequences. In three categories, molecular function contained the most numerous GO terms and gene number $(3,990)$, followed by biological process $(3,449)$ and cellular component (1,949; Supplementary Figure 3). In KEGG metabolism annotations of $\mathrm{XN}-04$, of the six classifications of KEGG pathways, metabolism contained the most number of genes, followed by environmental information processing (Supplementary Figure 4). Additionally, the results showed that 285 genes were identified from CAZy families and are distributed into five classes. A total of 108 proteins were predicted as belonging to the Glycoside Hydrolase (GH) family, 66 to Glycosyl Transferases (GTs), 63 to Carbohydrate Esterases (CEs), 22 to Auxiliary Activities (AAs), 20 to CarbohydrateBinding Modules, and 6 to the Polysaccharide Lyases (PLs) family (Supplementary Figure 5).

\section{Genome Analysis of Secondary Metabolite Clusters}

Genome mining of the $\mathrm{XN}-04$ genome revealed that this strain has the potential to produce a wealth of secondary metabolites. Up to 34 putative gene clusters for secondary metabolite biosynthesis located to the $8.25 \mathrm{Mb}$ chromosome of XN-04 as determined by antiSMASH 6.0 online software (Table 2). Among these clusters, three encode non-ribosomal peptides (NRPS, including biosynthesis mirubactin, streptolydigin, and coelichelin); one encodes type I polyketide synthases (PKS I, including biosynthesis ebelactone); two encode PKS III (including biosynthesis alkylresorcinol and violapyrone B); four are responsible for hybrid peptide polyketide; and five appear to code for terpene (Table 2). The remaining 19 gene clusters are mainly involved in the biosynthesis of ectoine, siderophore, bacteriocin, etc. Notably, XN-04 shows high similarity (100\%) with seven known clusters.

\section{Genes Associated With Fungal Cell Wall Degrading Enzymes}

$\mathrm{XN}-04$ contains various genes encoding specific enzymes involved in the degradation of chitin, including eight chitinases (seven from the GH18 family and one from the GH19 family), six $\beta$-N-acetyl hexosaminidase (three from the $\mathrm{GH} 3$ family and three from the GH20 family), and one chitosanase from the GH46 family. In addition, XN-04 also has six chitin-binding protein from the AA10 family, which enhance the binding abilities of enzymes to insoluble substrates. Details of the enzymes are listed in Supplementary Table S4. For the degradation of glucan, XN-04 harbors four genes encoding endo-1, 3- $\beta$-glucanase (three from the GH16 family and one from the GH64 family; Table S4). Moreover, XN-04 contains a variety of genes encoding enzymes that are thought to be involved in the degradation of cellulose, protein, and lipids (Supplementary Tables S4, S5).

\section{Genes Associated With Plant Growth Promotion}

Bioinformatics analysis of the $\mathrm{XN}-04$ genome showed the presence of several genes contributing directly or indirectly to plant growth-promoting activities. 

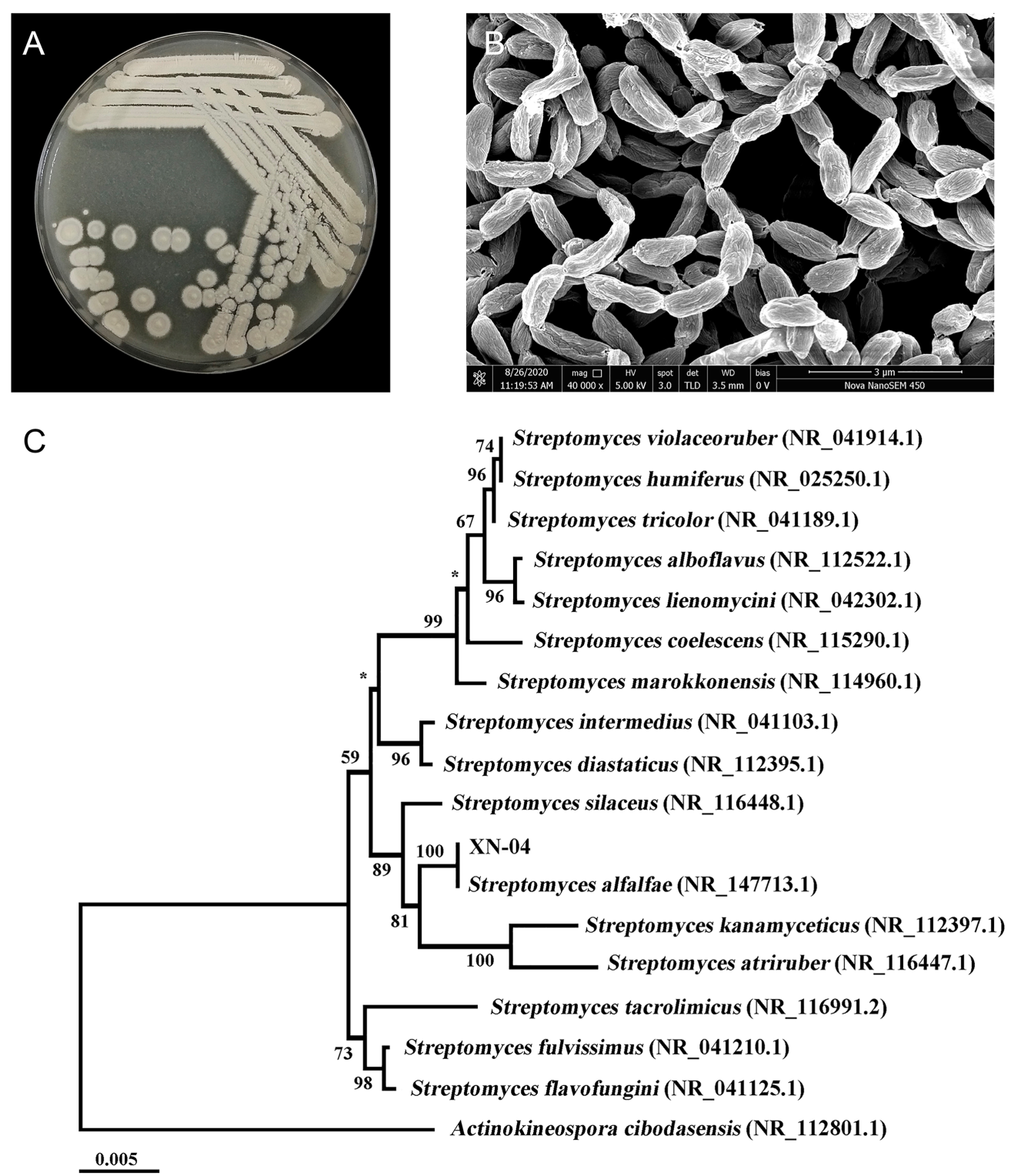

FIGURE 3 | Identification of XN-04. (A) Colony morphology of XN-04 on MS medium after 14 days of incubation at $28^{\circ} \mathrm{C}$. (B) SEM of XN-04 grown on MS medium for 14 days at $28^{\circ} \mathrm{C}$. (C) A phylogenetic tree based on $16 \mathrm{~S}$ rRNA gene sequences showing the phylogenetic position of XN-04 and the type strains of related taxa. The branches are scaled in terms of the expected number of substitutions per site (see bar). Support values from neighbor-joining bootstrapping are shown above the branches if $>50 \%$. Bar, 0.005 expected substitutions per site.

\section{Plant Hormones}

Three trp-dependent indole-3-acetic acid biosynthesis pathways, the indole acetamide (IAM), indole-acetonitrile (IAN), and the tryptamine (TAM) pathways appear to be involved in the IAA biosynthetic capacity of XN-04. In the IAM pathway, tryptophan can be directly converted to IAM by a tryptophan monooxygenase enzyme. Then IAM is converted to IAA by the action of the amidase enzyme. Six tryptophan 2-monooxygenase encoding genes and three amidase encoding genes are found in the $\mathrm{XN}-04$ chromosome (Supplementary Table S6). In the TAM pathway, tryptophan can be converted to TAM, which is subsequently converted to indole-3-acetaldehyde (IAAld) by an amine oxidase. Then, the IAAld is converted to IAA by the action of an aldehyde dehydrogenase enzyme. Two monoamine oxidase encoding genes and four aldehyde dehydrogenase are present in the $\mathrm{XN}-04$ chromosome (Supplementary Table S6). In addition, $\mathrm{XN}-04$ also contains a nitrilase encoding gene, which is involved in the process of transforming IAN to IAA via the IAN pathway (Supplementary Table S5). The presence of three separate IAA biosynthesis pathways in $\mathrm{XN}-04$ indicates that IAA production plays an important role in $\mathrm{XN}-04$ plant growthpromoting activities. 


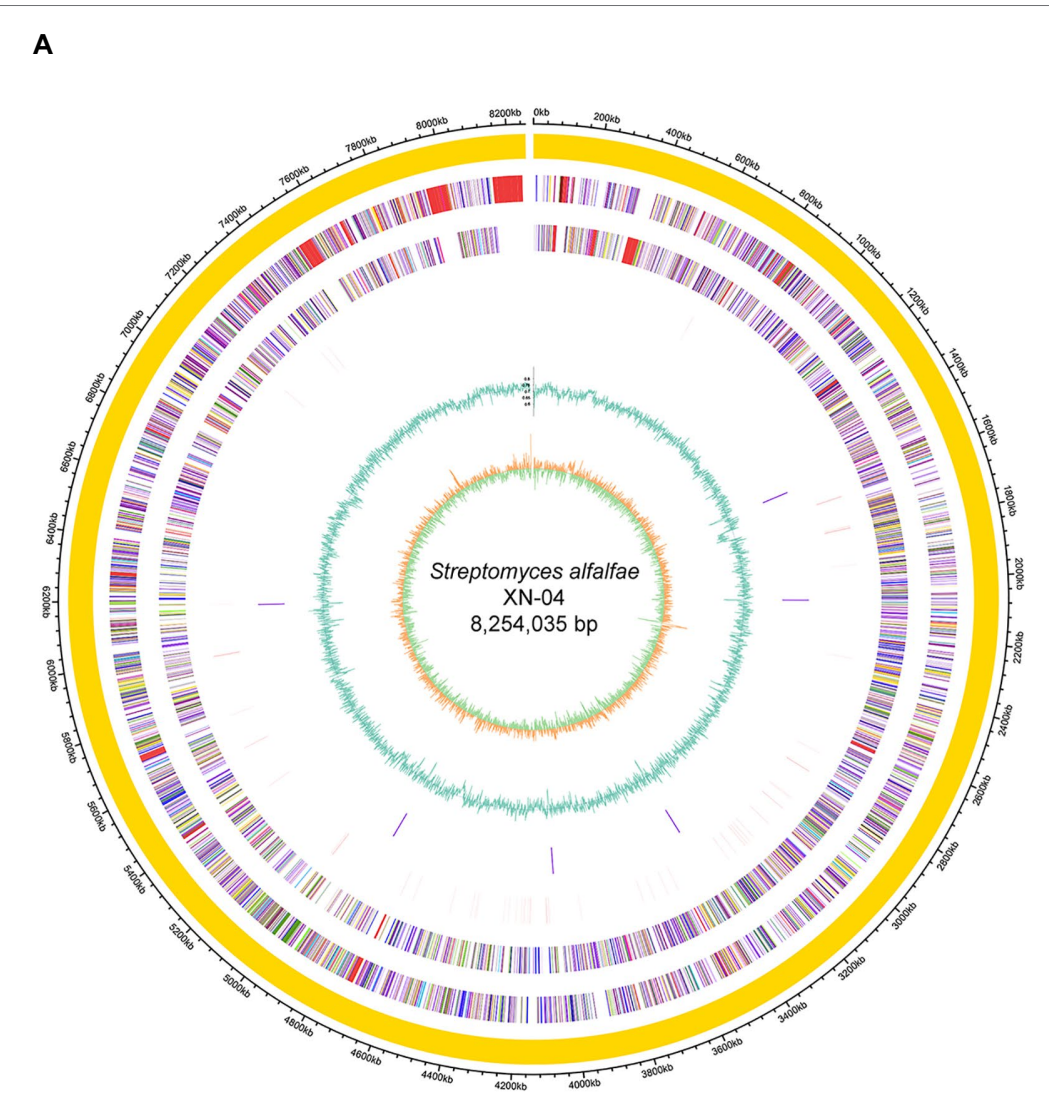

B

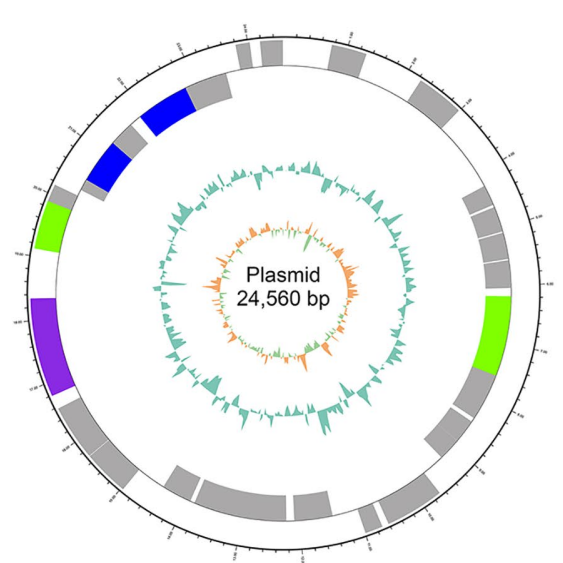

INFORMATION STORAGE AND PROCESSING

$\mathrm{J}$ : Translation, ribosomal structure and biogenesis

A: RNA processing and modification

K: Transcription

- L: Replication, recombination and repair

iructure and dynamics

CELLULAR PROCESSES AND SIGNALING

D: Cell cycle control, cell division, chromosome partitioning

$\mathrm{V}$ : Defense mechanisms

T: Signal transduction mechanisms

M: Cell wall/membrane/envelope biogenesis

METABOLISM

U: Intracellular trafficking, secretion, and vesicular transport

O: Posttranslational modification, protein turnover, chaperones

C: Energy production and conversion

G: Carbohydrate transport and metabolism

E: Amino acid transport and metabolism

: Nucleotide transport and metabolism

H: Coenzyme transport and metabolism

I: Lipid transport and metabolism

Q:

nythesis, transport and catabolism POORLY CHARACTERIZED

S: Function unknown

FIGURE 4 | Genome map of XN-04. (A) Genetic map of the circular chromosome; (B) genetic map of the circular plasmid. The circular map consists of six circles, from the outside circle to the inward. Circle 1 shows the distribution of genes related to COG categories in the forward strand; circle 2 shows CDS region including tRNA, rRNA, and others in forward strand; circle 3 shows CDS region including tRNA, rRNA, and others in the backward strand; circle 4 shows the distribution of genes related to COG categories in the backward strand; circle 5 shows the GC content; and circle 6 shows the GC skew.

TABLE 1 | Genome features of Streptomyces alfalfae XN-04.

\begin{tabular}{|c|c|c|c|}
\hline Features & Chromosome & Plasmid & Genome \\
\hline Genome topology & Linear & Circular & - \\
\hline Assembly size (bp) & $8,254,035 b p$ & $24,560 \mathrm{bp}$ & $8,278,595 b p$ \\
\hline $\mathrm{G}+\mathrm{C}$ content $(\%)$ & 72.06 & 71.85 & 72.06 \\
\hline $\begin{array}{l}\text { Protein-coding } \\
\text { genes (CDSs) }\end{array}$ & 7,549 & 30 & 7,579 \\
\hline tRNA genes & 72 & 0 & 72 \\
\hline rRNA genes & 18 & 0 & 18 \\
\hline $\begin{array}{l}\text { Gene total length } \\
\text { (bp) }\end{array}$ & 7,297,671bp & $17,151 \mathrm{bp}$ & $7,314,822 \mathrm{bp}$ \\
\hline $\begin{array}{l}\text { Secondary } \\
\text { metabolite gene } \\
\text { clusters }\end{array}$ & 33 & 0 & 33 \\
\hline $\begin{array}{l}\text { GenBank } \\
\text { accession }\end{array}$ & СР060742 & СР060743 & - \\
\hline
\end{tabular}

Additionally, XN-04 also contains a putative ACC deaminase that can decompose ACC (Supplementary Table S6) and thus inhibit ethylene synthesis in plants to improve the ability of plants to survive under adverse conditions and to provide adaptability to the environment.

\section{Siderophore Biosynthesis and Transport}

The XN-04 genome contains abundant genetic elements involved in siderophore biosynthesis and iron complex transport (Supplementary Table S7). Moreover, three siderophore biosynthesis clusters (cluster 12, 19, and 20) are also present in the chromosome sequence of XN-04 (Table 2). Notably, cluster 22 shows $100 \%$ similarity to the biosynthetic gene cluster of coelichelin in S. coelicolor A3(2), including a siderophore biosynthesis protein gene (gene6002) and eight genes related to iron transport (gene 5,989, gene5997, gene5998, gene5999, gene6000, gene6001, gene6003, and gene6014).

\section{Phosphate Solubilization}

Strain XN-04 genomic DNA contains two $p p x$ genes encoding exopolyphosphatase, and a $p p a$ gene encoding for inorganic pyrophosphatase, that are involved in the degradation of inorganic polyphosphates. The strain $\mathrm{XN}-04$ genome also contains four phoD genes, encoding alkaline phosphatase, which are involved in organic phosphate solubilization. Furthermore, one pstABCS phosphate transport system is found in the chromosomal DNA and involved in the transport and degradation of phosphonates (Supplementary Table S8). 
TABLE 2 | Secondary metabolite clusters in S. alfalfae XN-04.

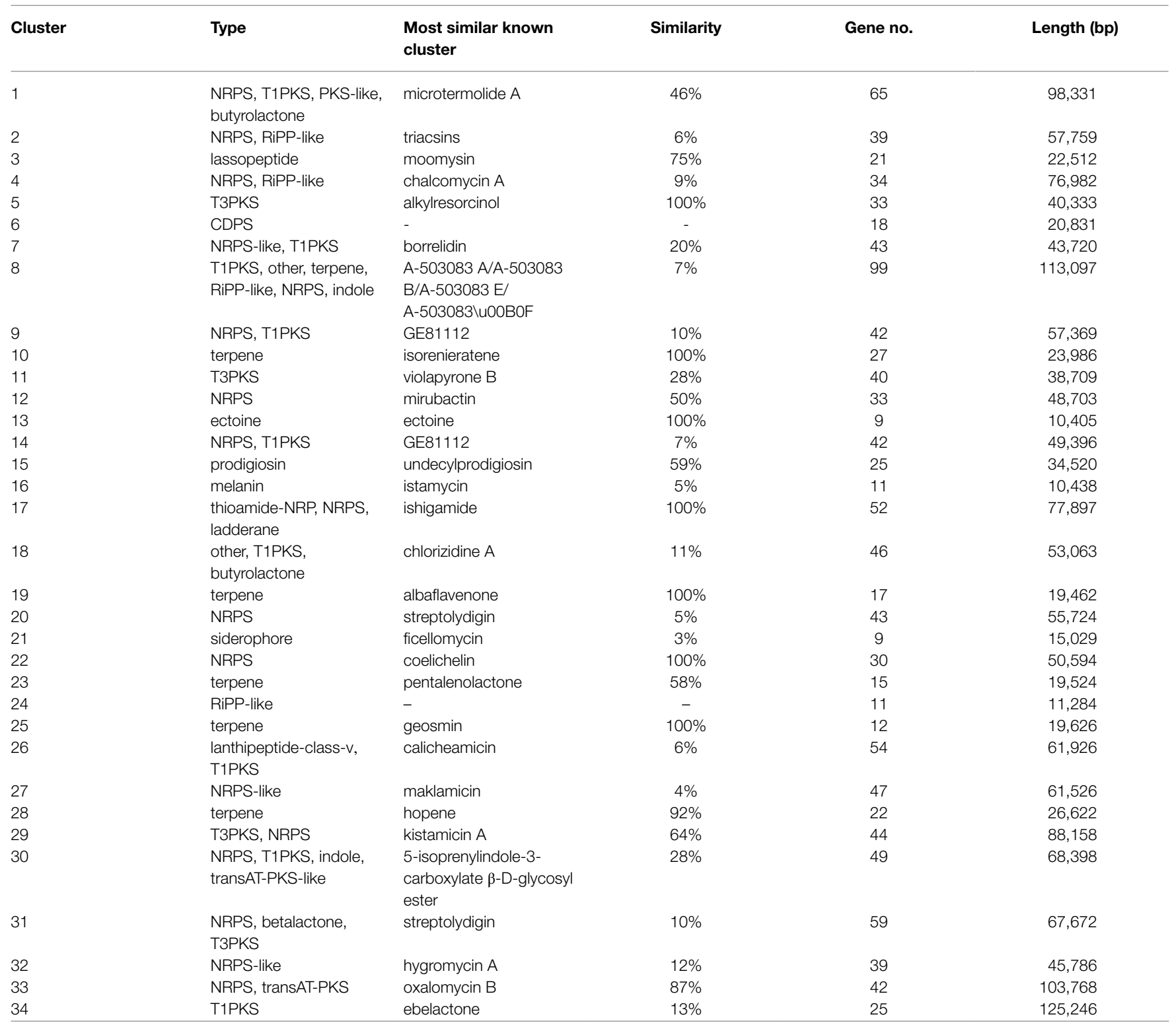

\section{Enzymes and Secondary Metabolites Production}

In vitro tests suggested that $\mathrm{XN}-04$ could grow well on colloidal chitin, glucan, sodium carboxymethyl cellulose, casein, and Rhodamine B medium, with a clear zone surrounding the colonies as a result of substrate hydrolysis indicating that XN-04 could secrete chitinase, $\beta-1,3$ glucanase, cellulose, protease, and lipase (Table 3). Moreover, XN-04 showed the ability to decolor the blue-colored ferric CAS complex into orange, revealing the production of siderophore. In addition, XN-04 was able to solubilize organic phosphate and showed a remarkable ability to produce plant hormones IAA and ACC deaminase (Table 3).

\section{Property of XN-04 Active Substances}

For the production of antifungal metabolites, fermentation was performed in GS broth for 14 days. After fermentation, $\mathrm{MeOH}$ extract of mycelia showed obvious antifungal activity against Fov, while the cell-free filtrates of XN-04 exhibited no inhibitory effects on the growth of Fov (Figure 5A). Further extraction revealed that all $\mathrm{XN}-04$ antifungal metabolites were concentrated in EtOAc fractions (Figure 5A). TLC using DCM: $\mathrm{MeOH}$ $(6: 1, \mathrm{v} / \mathrm{v})$ as solvent system resulted in separation of five antifungal metabolites in the EtOAc extract with $\mathrm{Rf}$ values of $0.93,0.88,0.33,0.25$, and 0.15 (Supplementary Figure 6).

The stability of these antifungal metabolites presented in $\mathrm{XN}-04$ to various physical and biochemical stresses was then examined to show the application performance of $\mathrm{XN}-04$ and 
TABLE 3 | Production of enzymes and secondary metabolites by $S$. alfalfae $\mathrm{XN}-04$.

\begin{tabular}{lclc}
\hline $\begin{array}{l}\text { Hydrolytic } \\
\text { activity }\end{array}$ & Trait & $\begin{array}{l}\text { Plant growth- } \\
\text { promoting } \\
\text { ability }\end{array}$ & Trait \\
\hline $\begin{array}{lll}\text { Chitinase } \\
\beta-1,3 \text { glucanase }\end{array}$ & + & $\begin{array}{l}\text { Siderophore } \\
\text { Indole Acetic Acid }\end{array}$ & + \\
Cellulase & + & (IAA) & + \\
Protease & + & Hydrogen cyanide & + \\
Lipase & & $\begin{array}{l}\text { HCN) } \\
\text { ACC deaminase }\end{array}$ & + \\
& + & $\begin{array}{l}\text { Organophosphate } \\
\text { solubilization }\end{array}$ & + \\
Inorganic & - \\
& + & $\begin{array}{l}\text { phosphate } \\
\text { solubilization }\end{array}$ & \\
\hline
\end{tabular}

"+" Positive reaction; "-" Negative reaction.

its metabolites. According to the acid-base stability assay, the antifungal activity of EtOAc extract declined markedly after exposure to acidic conditions at a $\mathrm{pH}$ of 2 or lower. However, the antifungal activity showed no significant difference at a $\mathrm{pH}$ within the range of 2 to 10 (Figure $5 \mathbf{B}$ ). The antifungal activity remained unchanged after being kept at $100^{\circ} \mathrm{C}$ for $1 \mathrm{~h}$ but decreased significantly at $121^{\circ} \mathrm{C}$ (Figure 5C). Furthermore, these metabolites were found to be stable when treated with light, UV, and proteinase K (Figures 5D-F). Therefore, it is undeniable that $\mathrm{XN}-04$ was stable under most conditions, which might indicate its biotechnological potential in fields under varying climatic conditions and in different regions.

\section{GC-MS Analysis}

From the GC-MS analysis, 29 chemical compounds of the $\mathrm{MeOH}$ extract of XN-04 were identified by the NIST library based on their retention time, molecular mass, and molecular formula (Supplementary Table S9). Among these compounds (1) n-hexadecanoic acid, (2) 9,12-octadecadienoic acid (Z,Z)-, methyl ester, (3) 9,12-octadecadienoic acid (Z,Z)-, (4) 9-octadecenoic acid (Z)-, and (5) bis(2-ethylhexyl) phthalate were reported with antifungal activity (Walters et al., 2004; Rahman and Anwar, 2006; Pinto et al., 2017; Qi et al., 2019).

\section{Colonization of $\mathrm{XN}-04$ in Cotton Roots}

To confirm whether XN-04 colonized cotton roots, a plasmid pIJ8641 containing the enhanced green fluorescent protein (EGFP) gene was transfected into XN-04 to construct an EGFPlabeled XN-04. The EGFP gene was detected in XN-04 and its expression was confirmed by CLSM observation. After transformation, the growth rate, mycelium morphology, and inhibiting effect on Fov were detected and they are similar to the wild-type XN-04 (data not shown). At the 2th, 4th, and 7 th day after inoculation, cotton seedling roots were observed by CLSM. No XN-04 cells were observed in the uninoculated cotton seedlings (data not shown). Two days after inoculation, a few EGFP-labeled XN-04 was found adhered to the surface of the cotton lateral roots (Figures $\mathbf{6 A - C}$ ). At the 4 th day after inoculation, $\mathrm{XN}-04$ cells were found to have colonized the surfaces of both the primary and lateral roots in the maturation zone (Figures 6D-F). CLSM results at the 7 th day after inoculation revealed that the number of EGFP-labeled $\mathrm{XN}-04$ accumulated on cotton roots had increased (Figures 6G-I).

The colonization density of the EGFP-labeled XN-04 in the cotton rhizosphere was further quantified using the traditional plating count method. With increasing time following inoculation, the number of EGFP-labeled XN-04 was found to have increased in cotton rhizosphere. The highest number of bacteria was reached on the 7 th day post-inoculation at $1.33 \times 10^{6} \mathrm{cfu} / \mathrm{g}$ root weight (Supplementary Table S10).

\section{DISCUSSION}

A considerable number of actinomycetes, especially Streptomyces spp., have been selected as BCAs promising resources for the biocontrol of fungi-induced plant diseases (Cho et al., 2017; Fidan et al., 2019). Since biocontrol agent selection is not a simple task due to the complexity of the field environment, BCAs with multiple modes of action and functions should be selected for further studies rather than selecting a BCA with only one mode of action. In this study, S. alfalfae XN-04 was isolated from rhizosphere soil, which can colonize the cotton plant root system, inhibiting the mycelial growth of Fov by production of hydrolytic enzymes and antifungal secondary metabolites. More importantly, $\mathrm{XN}-04$ is a versatile plant growth-promoting streptomycete, apparently modulating plant growth and development. Considering its above excellent traits, strain XN-04 may have great potential to be developed as a novel BCA for Fusarium wilt in future.

\section{The Colonization Ability of XN-04}

Effective colonization on plant roots is crucial for the biocontrol of soil-borne plant diseases by BCA (Ye et al., 2020). Before a species can be selected as a BCA, the level of root colonization must be determined. It must be able to compete favorably against other microbes to be able to exert its influence on the host plants. Coombs and Franco (2003) demonstrated the endophytic colonization of GFP-labeled Streptomyces sp. EN27 was observed from a very early stage of plant development with colonization of the embryo, endosperm, and emerging radicle of wheat. Chen et al. (2016) reported that the abundant colonization of young lettuce seedlings by the EGFP-labeled S. exfoliatus FT05W demonstrated Streptomyces' capability to interact with the host from early stages of seed germination and root development. In this study, CLSM observation indicated that $\mathrm{XN}-04$ began to colonize the roots of young cotton seedlings at 2 days after inoculation (Figure 6). The strain $\mathrm{XN}-04$ quantity in cotton root surrounding soil reached a level of $1.33 \times 10^{6} \mathrm{cfu} / \mathrm{g}$ root at 7 days after inoculation (Supplementary Table S10). This finding suggests that XN-04 was well adapted to the rhizosphere soil environment. 

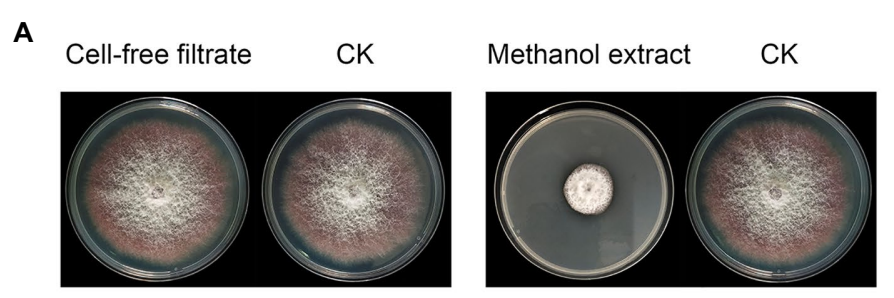

EtOAc extract $\quad \mathrm{CK}$

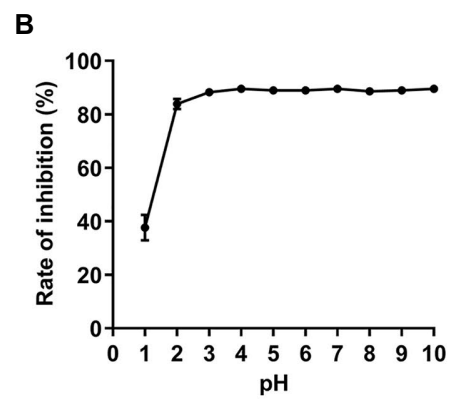

C

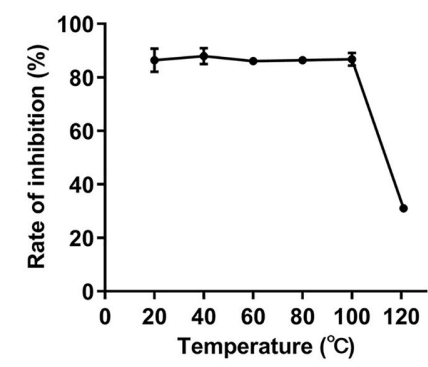

D
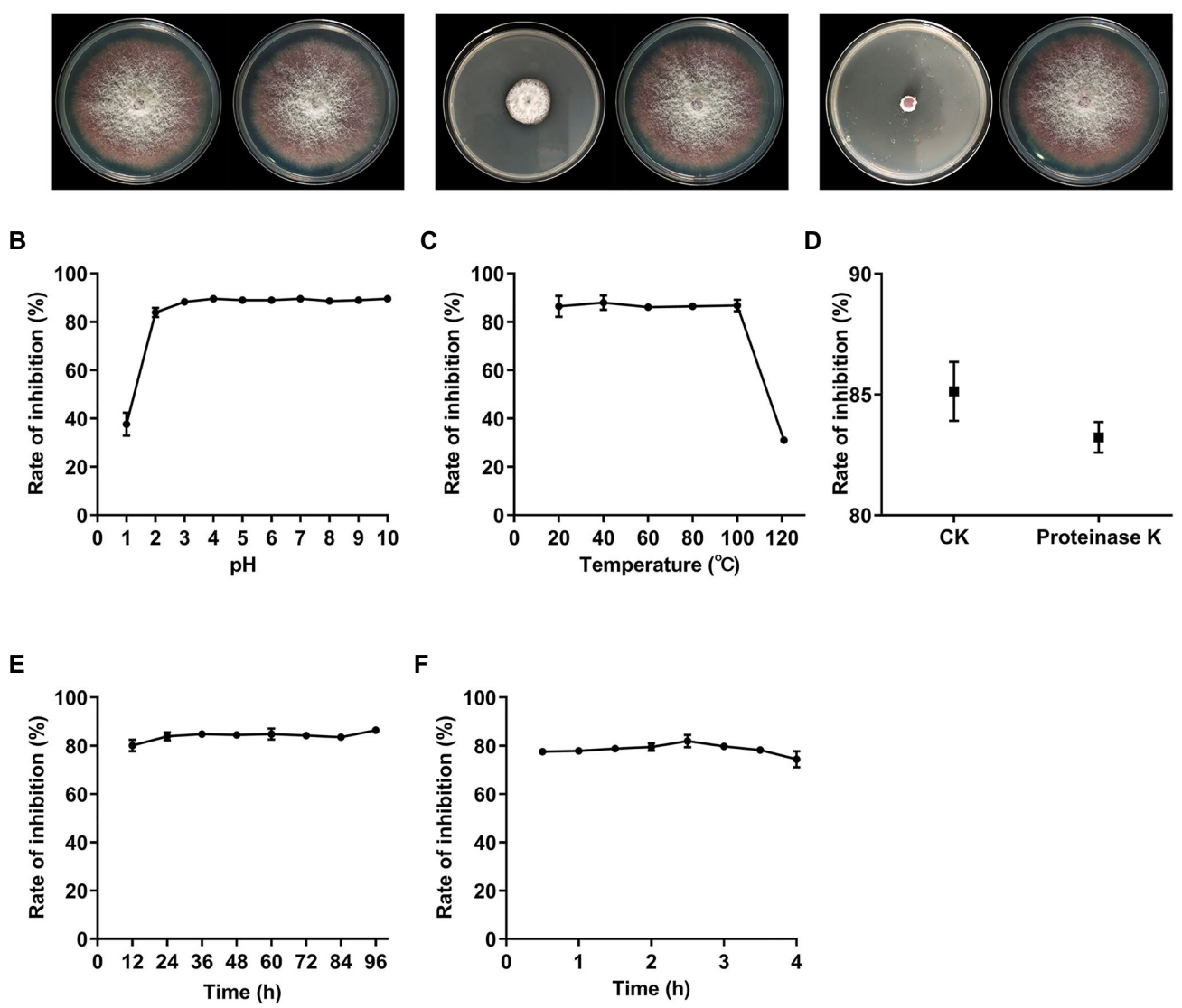

$\mathbf{F}$

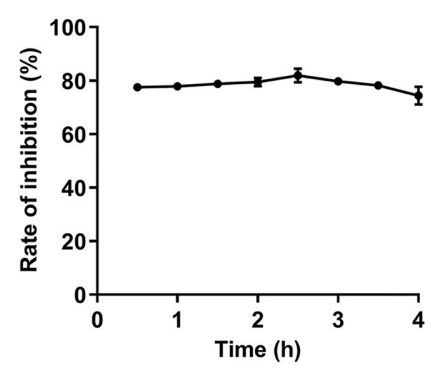

FIGURE 5 | The distribution and stability of active substances. (A) Antagonistic activities against Fov of secondary metabolites extracted from XN-04. (B) The effect of temperature (C) pH (D) proteinase K (E) lighting, and (F) UV on XN-04 active substances. Data are mean $\pm \mathrm{SD}(n=3)$.

Biochemical tests revealed that $\mathrm{XN}-04$ is able to use a rather wide range of compounds as carbon and nitrogen sources, which confer a significant advantage to the plant colonization ability. Additionally, XN-04 exhibited a good tolerance to salt as it grew in the presence of $0-8 \%(\mathrm{w} / \mathrm{v}) \mathrm{NaCl}$. In the study, an ectoine biosynthesis cluster was found in the $\mathrm{XN}-04$ chromosome (Table 3). Ectoine is one of the most important synthetic osmotic compatible solutes for moderate halophilic bacteria, which can also equilibrate the osmotic pressure of cells, as well as provide a reversible assistance to enzymes, DNA, and the whole cell in adverse environments (Prabhu et al., 2004). All of these properties suggest that $S$. alfalfae $\mathrm{XN}-04$ may have the ability to adapt to the complex field soil conditions.

\section{Antifungal Metabolites Analysis of XN-04}

Highly active hydrolytic enzymes including chitinases, $\beta-1,3$ glucanase, and protease, produced by Streptomyces spp., may confer capability for competing in the rhizosphere environment, destroying the cell walls of phytopathogenic fungi, and making these microorganisms promising for biocontrol use (Vurukonda et al., 2018). Since chitin is the most abundant component of the fungal cell wall, chitinases have been widely demonstrated to be important inhibitors of fungal growth (Taechowisan et al., 2003). A recent study showed that the GH19 chitinase cloned from S. alfalfae ACCC40021 exhibited great capability for inhibiting the growth of phytopathogenic fungi ( $\mathrm{Lv}$ et al., 2021). In the present study, XN-04 exhibited the ability to degrade chitin on agar plates, which was also confirmed by the identification of the genes related to chitin degradation in its genome. Therefore, we hypothesize that the excellent biocontrol property of $\mathrm{XN}-04$ may be related to chitinase produced by XN-04.

Apart from hydrolytic enzymes, the function of bioactive secondary metabolites produced by Streptomyces spp. cannot be underestimated for controlling fungal diseases (Olanrewaju and Babalola, 2019). In this study, antiSMASH analysis revealed that a total of 34 secondary metabolites BGCs are present in the genome of the XN-04. S. alfalfae XN-04 shows a high similarity ( $\geq 75 \%$ ) with 10 known clusters (Table 3 ), but none of these compounds have been reported for antifungal activity. Thus, the antifungal metabolites of $\mathrm{XN}-04$ may be new or may have another biosynthesis pathway or uncharacterized 

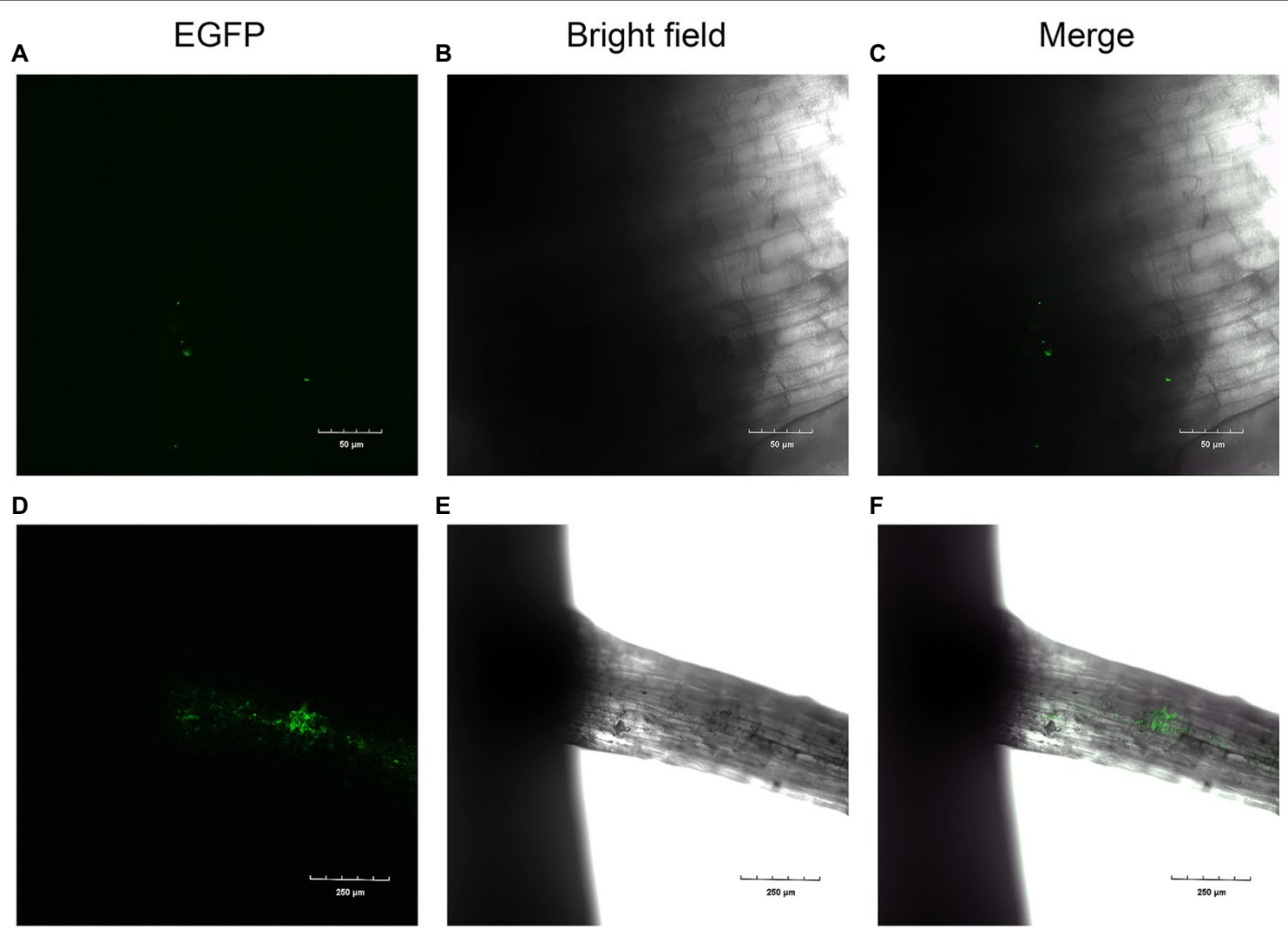

E

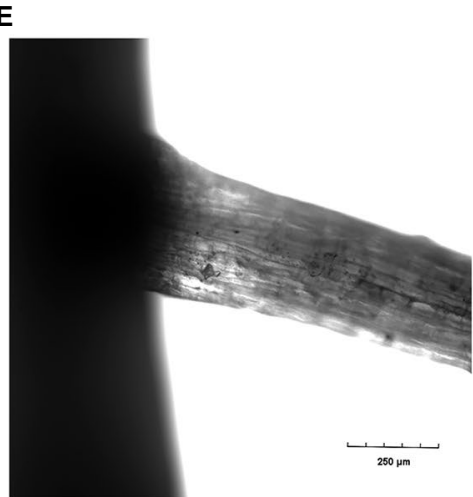

$\mathbf{F}$

$\mathbf{G}$

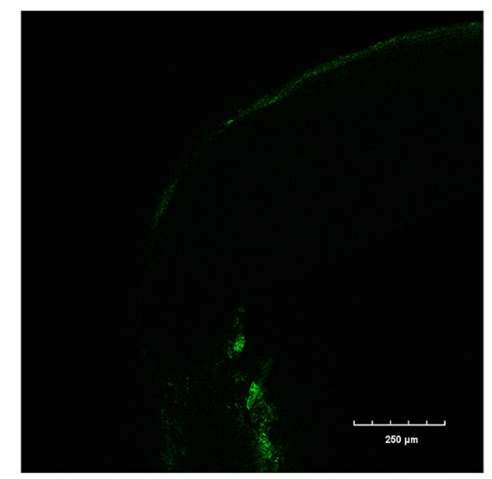

H

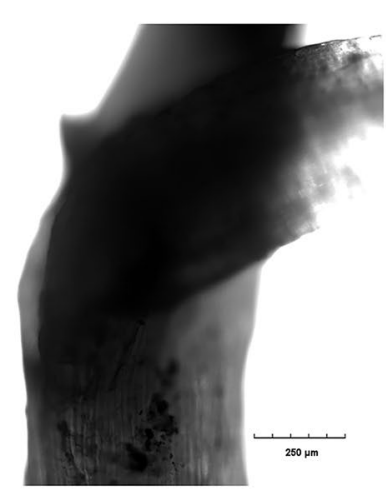

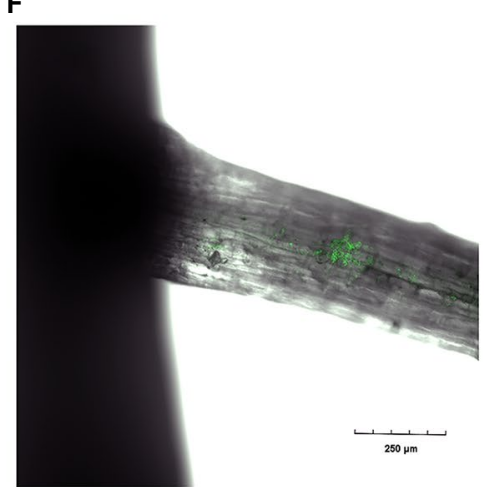

I

FIGURE 6 | Colonization of cotton roots by EGFP-labeled XN-04. Colonization after (A, B, and C) 2 days; (D, E, and F) 4 days; and (G, H, and I) 7 days.

mechanism. Further studies revealed that the EtOAc extract of XN-04 inhibited the growth of Fov at very low concentrations. The antifungal activity of EtOAc extract indicated no significant reduction after treatment with heat and proteinase $\mathrm{K}$, suggesting that the antifungal metabolites of $\mathrm{XN}-04$ may be not proteins. A total of 29 compounds from $\mathrm{MeOH}$ extract were identified by GC-MS in our present study (Table S10), among which (1) n-hexadecanoic acid, (2) 9,12-octadecadienoic acid (Z,Z)-, methyl ester, (3) 9,12-octadecadienoic acid (Z,Z)- (4) 9-octadecenoic acid, (Z)-, and (5) bis(2-ethylhexyl) phthalate have been reported with antifungal activity in previous studies (Walters et al., 2004; Rahman and Anwar, 2006; Pinto et al., 2017; Qi et al., 2019). Therefore, we hypothesize that XN-04 might control Fov using multiple metabolites. To date, it is still unclear whether these compounds are related to the biocontrol ability of $\mathrm{XN}-04$, which merit further investigation in the future study.

\section{The Mechanisms of XN-04 Promoting Plant Growth}

Many BCAs have the characteristics of promoting plant growth and facilitating the absorption and utilization of mineral nutrients, which confers them additional advantages in the disease suppression process (Olanrewaju and Babalola, 2019). In this study, XN-04 was demonstrated to effectively promote cotton growth under greenhouse conditions. Previous study has documented that the secretion of IAA and ACC deaminase 
is very important for the growth-promoting activity of Streptomyces spp. (Vurukonda et al., 2018). El-Tarabily (2008) reported that the increased growth promoted by S. filipinensis, when compared to $S$. atrovirens, was due to the production of both IAA and ACC, whereas S. atrovirens only produced ACC deaminase.

Streptomyces alfalfae XN-04 also exhibited other interesting PGP activities, such as siderophore production and phosphate solubilization. Siderophore compounds are potential plant growth promoters and disease suppressors. Streptomyces spp. was reported to produce hydroxymate-type siderophores, which inhibit the growth of phytopathogens by limiting iron in the rhizosphere (Khamna et al., 2009). Notably, KEGG together with antiSMASH analysis showed that $\mathrm{XN}-04$ exhibited the great potential to synthesize multiple types of siderophore, i.e., enterobactin, coelichelin, mirubactin, and a NRPS-independent siderophore. The existence of siderophores with various chelating groups in the same strain can benefit the microorganism itself, thus improving its competitiveness in the environment. It can be presumed that the suppression of plant growth-promoting by $\mathrm{XN}-04$ might be due to these mechanisms, but further studies are required to provide evidence regarding the actual mechanisms.

\section{DATA AVAILABILITY STATEMENT}

The datasets presented in this study can be found in online repositories. The names of the repository/repositories and accession number(s) can be found in the article/Supplementary Material.

\section{REFERENCES}

Abbasi, S., Safaie, N., Sadeghi, A., and Shamsbakhsh, M. (2019). Streptomyces strains induce resistance to Fusarium oxysporum f. sp. lycopersici race 3 in tomato through different molecular mechanisms. Front. Microbiol. 10:1505. doi: $10.3389 /$ fmicb.2019.01505

Apweiler, R., Bairoch, A., Wu, C. H., Barker, W. C., Boeckmann, B., Ferro, S., et al. (2004). UniProt: the universal protein knowledgebase. Nucleic Acids Res. 32, D115-D119. doi: 10.1093/nar/gkh131

Ashburner, M., Ball, C. A., Blake, J. A., Botstein, D., Butler, H., Cherry, J. M., et al. (2000). Gene ontology: tool for the unification of biology. The gene ontology consortium. Nat. Genet. 25, 25-29. doi: 10.1038/75556

Awla, H. K., Kadir, J., Othman, R., Rashid, T. S., Hamid, S., and Wong, M. Y. (2017). Plant growth-promoting abilities and biocontrol efficacy of Streptomyces sp. UPMRS4 against Pyricularia oryzae. Biol. Control 112, 55-63. doi: 10.1016/j. biocontrol.2017.05.011

Baltz, R. H. (2016). Genetic manipulation of secondary metabolite biosynthesis for improved production in Streptomyces and other actinomycetes. J. Ind. Microbiol. Biotechnol. 43, 343-370. doi: 10.1007/s10295-0151682-x

Bankevich, A., Nurk, S., Antipov, D., Gurevich, A. A., Dvorkin, M., Kulikov, A. S., et al. (2012). SPAdes: a new genome assembly algorithm and its applications to single-cell sequencing. J. Comput. Biol. 19, 455-477. doi: 10.1089/ cmb.2012.0021

Blin, K., Shaw, S., Kloosterman, A. M., Charlop-Powers, Z., van Wezel, G. P., Medema, M. H., et al. (2021). antiSMASH 6.0: improving cluster detection and comparison capabilities. Nucleic Acids Res. 49, W29-W35. doi: 10.1093/ nar/gkab335

\section{AUTHOR CONTRIBUTIONS}

JC and YW designed the study and wrote the manuscript. JC, LH, NC, and RJ performed the experiments. JC, LH, NC, and YW analyzed the data. QM helped to revise the manuscript. All authors contributed to the article and approved the submitted version.

\section{FUNDING}

This work was supported by the National Key R\&D Program of the Ministry of Science and Technology (2018YFD0201205-2) and the Key Industry Chain Innovation Project of Shaanxi province (2020ZDLNY07-02).

\section{ACKNOWLEDGMENTS}

The authors would like to thank Professor Mervyn Bibb from the Department of Molecular Microbiology, John Innes Centre, Norwich, NR4 7UH (UK) for providing us with plasmid pIJ8641, and the authors thank Professor John Richard Schrock for proofreading our paper.

\section{SUPPLEMENTARY MATERIAL}

The Supplementary Material for this article can be found online at: https://www.frontiersin.org/articles/10.3389/fmicb. 2021.745766/full\#supplementary-material

Bonaldi, M., Chen, X. Y. L., Kunova, A., Pizzatti, C., Saracchi, M., and Cortesi, P. (2015). Colonization of lettuce rhizosphere and roots by tagged Streptomyces. Front. Microbiol. 6:25. doi: 10.3389/fmicb.2015.00025

Chen, C., Bauske, E. M., Musson, G., Rodriguezkabana, R., and Kloepper, J. W. (1995). Biological control of Fusarium wilt on cotton by use of endophytic bacteria. Biol. Control 5, 83-91. doi: 10.1006/bcon.1995.1009

Chen, X., Pizzatti, C., Bonaldi, M., Saracchi, M., Erlacher, A., Kunova, A., et al. (2016). Biological control of lettuce drop and host plant colonization by rhizospheric and endophytic streptomycetes. Front. Microbiol. 7:714. doi: 10.3389/fmicb.2016.00714

Chen, Y., Wang, J., Yang, N., Wen, Z. Y., Sun, X. P., Chai, Y. R., et al. (2018). Wheat microbiome bacteria can reduce virulence of a plant pathogenic fungus by altering histone acetylation. Nat. Commun. 9:3429. doi: 10.1038/ s41467-018-05683-7

Cho, G., Kim, J., Park, C. G., Nislow, C., Weller, D. M., and Kwak, Y. S. (2017). Caryolan-1-ol, an antifungal volatile produced by Streptomyces spp., inhibits the endomembrane system of fungi. Open Biol. 7:170075. doi: 10.1098/rsob.170075

Choi, S. S., Kim, H. J., Lee, H. S., Kim, P., and Kim, E. S. (2015). Genome mining of rare actinomycetes and cryptic pathway awakening. Process Biochem. 50, 1184-1193. doi: 10.1016/j.procbio.2015.04.008

Cianchetta, A. N., and Davis, R. M. (2015). Fusarium wilt of cotton: management strategies. Crop Prot. 73, 40-44. doi: 10.1016/j.cropro.2015.01.014

Coombs, J. T., and Franco, C. M. (2003). Visualization of an endophytic Streptomyces species in wheat seed. Appl. Environ. Microbiol. 69, 4260-4262. doi: 10.1128/AEM.69.7.4260-4262.2003

Cox, K. L., Babilonia, K., Wheeler, T., He, P., and Shan, L. (2019). Return of old foes - recurrence of bacterial blight and Fusarium wilt of cotton. Curr Opin. Plant Biol. 50, 95-103. doi: 10.1016/j.pbi.2019.03.012 
Delcher, A. L., Bratke, K. A., Powers, E. C., and Salzberg, S. L. (2007). Identifying bacterial genes and endosymbiont DNA with glimmer. Bioinformatics 23, 673-679. doi: 10.1093/bioinformatics/btm009

Diaz-Gutierrez, C., Arroyave, C., Llugany, M., Poschenrieder, C., Martos, S., and Pelaez, C. (2021). Trichoderma asperellum as a preventive and curative agent to control Fusarium wilt in Stevia rebaudiana. Biol. Control 155:104537. doi: 10.1016/j.biocontrol.2021.104537

El-Tarabily, K. A. (2008). Promotion of tomato (Lycopersicon esculentum mill.) plant growth by rhizosphere competent 1-aminocyclopropane-1-carboxylic acid deaminase-producing streptomycete actinomycetes. Plant Soil 308, 161-174. doi: 10.1007/s11104-008-9616-2

Fatima, S., and Anjum, T. (2017). Identification of a potential ISR determinant from Pseudomonas aeruginosa PM12 against Fusarium wilt in tomato. Front. Plant Sci. 8:848. doi: 10.3389/fpls.2017.00848

Fidan, O., Yan, R. M., Zhu, D., and Zhan, J. X. (2019). Improved production of antifungal angucycline Sch47554 by manipulating three regulatory genes in Streptomyces sp. SCC-2136. Biotechnol. Appl. Biochem. 66, 517-526. doi: 10.1002/bab. 1748

Finn, R. D., Bateman, A., Clements, J., Coggill, P., Eberhardt, R. Y., Eddy, S. R., et al. (2014). Pfam: the protein families database. Nucleic Acids Res. 42, D222-D230. doi: 10.1093/nar/gkt1223

Guo, Q., Li, S., Lu, X., Gao, H., Wang, X., Ma, Y., et al. (2015). Identification of a new genotype of Fusarium oxysporum $\mathrm{f}$. sp. vasinfectum on cotton in China. Plant Dis. 99, 1569-1577. doi: 10.1094/PDIS-12-14-1238-RE

Heinsch, S. C., Hsu, S. Y., Otto-Hanson, L., Kinkel, L., and Smanski, M. J. (2019). Complete genome sequences of Streptomyces spp. isolated from disease-suppressive soils. BMC Genomics 20:994. doi: 10.1186/ s12864-019-6279-8

Hewedy, O. A., Abdel-Lateif, K. S., and Bakr, R. A. (2020). Genetic diversity and biocontrol efficacy of indigenous Trichoderma isolates against Fusarium wilt of pepper. J. Basic Microbiol. 60, 126-135. doi: 10.1002/jobm.201900493

Holt, J.G., Krieg, N.R., Snealth, P., and Staley, J.T. (1994). Bergey's Manual of Determinative Bacteriology. United States: Williams \& Wilkins Press.

Huang, Z., Wang, D. D., Li, J. P., Wei, C., and He, H. (2020). Transovarial transmission of bacteriome-associated symbionts in the cicada Pycna repanda (Hemiptera: Cicadidae). Appl. Environ. Microbiol. 86:e02957-19. doi: 10.1128/ AEM.02957-19

Hwang, K. S., Kim, H. U., Charusanti, P., Palsson, B. O., and Lee, S. Y. (2014). Systems biology and biotechnology of Streptomyces species for the production of secondary metabolites. Biotechnol. Adv. 32, 255-268. doi: 10.1016/j. biotechadv.2013.10.008

Jang, H. D., and Chen, K. S. (2003). Production and characterization of thermostable cellulases from Streptomyces transformant T3-1. World J. Microbiol. Biotechnol. 19, 263-268. doi: 10.1023/A:1023641806194

Jensen, L. J., Julien, P., Kuhn, M., von Mering, C., Muller, J., Doerks, T., et al. (2008). eggNOG: automated construction and annotation of orthologous groups of genes. Nucleic Acids Res. 36, D250-D254. doi: 10.1093/nar/gkm796

Kanehisa, M., and Goto, S. (2000). KEGG: Kyoto encyclopedia of genes and genomes. Nucleic Acids Res. 28, 27-30. doi: 10.1093/nar/28.1.27

Khamna, S., Yokota, A., and Lumyong, S. (2009). Actinomycetes isolated from medicinal plant rhizosphere soils: diversity and screening of antifungal compounds, indole-3-acetic acid and siderophore production. World $\mathrm{J}$. Microbiol. Biotechnol. 25, 649-655. doi: 10.1007/s11274-008-9933-x

Kieser, T., Bibb, M.J., Buttner, M.J., Chater, K.F., Hopwood, D.A., Charter, K., et al. (2000). Practical Streptomyces Genetics. Norwich, UK: John Innes Foundation Press.

Koren, S., Walenz, B. P., Berlin, K., Miller, J. R., Bergman, N. H., and Phillippy, A. M. (2017). Canu: scalable and accurate long-read assembly via adaptive k-mer weighting and repeat separation. Genome Res. 27, 722-736. doi: $10.1101 /$ gr.215087.116

Kumar, S., Stecher, G., and Tamura, K. (2016). MEGA7: molecular evolutionary genetics analysis version 7.0 for bigger datasets. Mol. Biol. Evol. 33, 1870-1874. doi: 10.1093/molbev/msw054

Larkin, M. A., Blackshields, G., Brown, N. P., Chenna, R., McGettigan, P. A., McWilliam, H., et al. (2007). Clustal W and clustal X version 2.0. Bioinformatics 23, 2947-2948. doi: 10.1093/bioinformatics/btm404

Lee, N., Kim, W., Hwang, S., Lee, Y., Cho, S., Palsson, B., et al. (2020). Thirty complete Streptomyces genome sequences for mining novel secondary metabolite biosynthetic gene clusters. Sci. Data. 7:55. doi: 10.1038/s41597-020-0395-9
Li, Y., Guo, Q., Wei, X., Xue, Q., and Lai, H. (2019). Biocontrol effects of Penicillium griseofulvum against monkshood (Aconitum carmichaelii Debx.) root diseases caused by Sclerotium rolfsiii and Fusarium spp. J. Appl. Microbiol. 127, 1532-1545. doi: 10.1111/jam.14382

Li, B., Li, Q., Xu, Z. H., Zhang, N., Shen, Q. R., and Zhang, R. F. (2014). Responses of beneficial bacillus amyloliquefaciens SQR9 to different soilborne fungal pathogens through the alteration of antifungal compounds production. Front. Microbiol. 5:636. doi: 10.3389/fmicb.2014.00636

Lowe, T. M., and Eddy, S. R. (1997). tRNAscan-SE: A program for improved detection of transfer RNA genes in genomic sequence. Nucleic Acids Res. 25, 955-964. doi: 10.1093/nar/25.5.955

Luo, W., Liu, L., Qi, G., Yang, F., Shi, X., and Zhao, X. (2019). Embedding bacillus velezensis $\mathrm{NH}-1$ in microcapsules for biocontrol of cucumber Fusarium wilt. Appl. Environ. Microbiol. 85:e03128-18. doi: 10.1128/AEM.03128-18

Lv, C. Y., Gu, T. Y., Ma, R., Yao, W., Huang, Y. Y., Gu, J. G., et al. (2021). Biochemical characterization of a GH19 chitinase from Streptomyces alfalfae and its applications in crystalline chitin conversion and biocontrol. Int. J. Biol. Macromol. 167, 193-201. doi: 10.1016/j.ijbiomac.2020.11.178

Mei, X., Liu, Y., Huang, H., Du, F., Huang, L., Wu, J., et al. (2019). Benzothiazole inhibits the growth of Phytophthora capsici through inducing apoptosis and suppressing stress responses and metabolic detoxification. Pestic. Biochem. Physiol. 154, 7-16. doi: 10.1016/j.pestbp.2018.12.002

Nascimento, F. X., Hernandez, A. G., Glick, B. R., and Rossi, M. J. (2020). The extreme plant-growth-promoting properties of Pantoea phytobeneficialis MSR2 revealed by functional and genomic analysis. Environ. Microbiol. 22, 1341-1355. doi: 10.1111/1462-2920.14946

Nieto-Jacobo, M. F., Steyaert, J. M., Salazar-Badillo, F. B., Nguyen, D. V., Rostas, M., Braithwaite, M., et al. (2017). Environmental growth conditions of Trichoderma spp. affects indole acetic acid derivatives, volatile organic compounds, and plant growth promotion. Front. Plant Sci. 8:102. doi: 10.3389/fpls.2017.00102

Olanrewaju, O. S., and Babalola, O. O. (2019). Streptomyces: implications and interactions in plant growth promotion. Appl. Microbiol. Biotechnol. 103, 1179-1188. doi: 10.1007/s00253-018-09577-y

Pan, H. Q., Tian, X. P., Shao, M. W., Xie, Y. C., Huang, H. B., Hu, J. C., et al. (2019). Genome mining and metabolic profiling illuminate the chemistry driving diverse biological activities of. Bacillus siamensis SCSIO 05746. Appl. Microbiol. Biotechnol. 103, 4153-4165. doi: 10.1007/s00253-019-09759-2

Peng, C., An, D. P., Ding, W. X., Zhu, Y. X., Ye, L., and Li, J. Y. (2020). Fungichromin production by Streptomyces sp. WP-1, an endophyte from Pinus dabeshanensis, and its antifungal activity against Fusarium oxysporum. Appl. Microbiol. Biotechnol. 104, 10437-10449. doi: 10.1007/s00253-020-10996-z

Pinto, M. E. A., Araujo, S. G., Morais, M. I., Sa, N. P., Lima, C. M., Rosa, C. A., et al. (2017). Antifungal and antioxidant activity of fatty acid methyl esters from vegetable oils. An. Acad. Bras. Cienc. 89, 1671-1681. doi: 10.1590/0001-3765201720160908

Prabhu, J., Schauwecker, F., Grammel, N., Keller, U., and Bernhardt, M. (2004). Functional expression of the ectoine hydroxylase gene (thpD) from Streptomyces chrysomallus in Halomonas elongata. Appl. Environ. Microbiol. 70, 3130-3132. doi: 10.1128/AEM.70.5.3130-3132.2004

Qi, D. F., Zou, L. P., Zhou, D. B., Chen, Y. F., Gao, Z. F., Feng, R. J., et al. (2019). Taxonomy and broad-spectrum antifungal activity of Streptomyces sp. SCA3-4 isolated from rhizosphere soil of Opuntia stricta. Front. Microbiol. 10:1390. doi: 10.3389/fmicb.2019.01390

Rahman, M. S., and Anwar, M. N. (2006). Fungitoxic and cytotoxic activity of a novel compound 1,2-benzenedicarboxylic acid, diisooctyl ester of Plumbago zeylanica Linn. Asian J. Microbiol. Biotechnol. Environ. Sci. 8, 461-464.

Raza, W., Ling, N., Zhang, R., Huang, Q., Xu, Y., and Shen, Q. (2017). Success evaluation of the biological control of Fusarium wilts of cucumber, banana, and tomato since 2000 and future research strategies. Crit. Rev. Biotechnol. 37, 202-212. doi: 10.3109/07388551.2015.1130683

Seemann, T., and Booth, T. (2018). Barrnap: BAsic Rapid Ribosomal RNA Predictor. Available at: https://github.com/tseemann/barrnap/ (Accessed May 1, 2019).

She, W., Sun, Z., Yi, L., Zhao, S., and Liang, Y. (2016). Streptomyces alfalfae sp. nov. and comparisons with its closest taxa Streptomyces silaceus, Streptomyces flavofungini and Streptomyces intermedius. Int. J. Syst. Evol. Microbiol. 66, 44-49. doi: $10.1099 /$ ijsem.0.000671

Song, Z., Ma, Z., Bechthold, A., and Yu, X. (2020). Effects of addition of elicitors on rimocidin biosynthesis in Streptomyces rimosus M527. Appl. Microbiol. Biotechnol. 104, 4445-4455. doi: 10.1007/s00253-020-10565-4 
Stothard, P., and Wishart, D. S. (2005). Circular genome visualization and exploration using CGView. Bioinformatics 21, 537-539. doi: 10.1093/ bioinformatics/bti054

Suarez-Moreno, Z. R., Vinchira-Villarraga, D. M., Vergara-Morales, D. I., Castellanos, L., Ramos, F. A., Guarnaccia, C., et al. (2019). Plant-growth promotion and biocontrol properties of three Streptomyces spp. isolates to control bacterial rice pathogens. Front. Microbiol. 10:290. doi: 10.3389/ fmicb.2019.00290

Taechowisan, T., Peberdy, J. F., and Lumyong, S. (2003). Chitinase production by endophytic Streptomyces aureofaciens CMUAc130 and its antagonism against phytopathogenic fungi. Ann. Microbiol. 53, 447-461.

Vurukonda, S. S. K. P., Giovanardi, D., and Stefani, E. (2018). Plant growth promoting and biocontrol activity of Streptomyces spp. as endophytes. Int. J. Mol. Sci. 19:952. doi: 10.3390/ijms19040952

Walters, D., Raynor, L., Mitchell, A., Walker, R., and Walker, K. (2004). Antifungal activities of four fatty acids against plant pathogenic fungi. Mycopathologia 157, 87-90. doi: 10.1023/b:myco.0000012222.68156.2c

Williams, S. T., Goodfellow, M., Alderson, G., Wellington, E. M., Sneath, P. H., and Sackin, M. J. (1983). Numerical classification of Streptomyces and related genera. J. Gen. Microbiol. 129, 1743-1813. doi: 10.1099/00221287-129-6-1743

Ye, X. F., Li, Z. K., Luo, X., Wang, W. H., Li, Y. K., Li, R., et al. (2020). A predatory myxobacterium controls cucumber Fusarium wilt by regulating the soil microbial community. Microbiome. 8:49. doi: 10.1186/ s40168-020-00824-X

Yu, S. M., Teng, C. Y., Liang, J. S., Song, T., Dong, L. Y., Bai, X., et al. (2017). Characterization of siderophore produced by pseudomonas syringae BAF.1 and its inhibitory effects on spore germination and mycelium morphology of Fusarium oxysporum. J. Microbiol. 55, 877-884. doi: 10.1007/ s12275-017-7191-z
Zhang, J., Chen, J., Hu, L., Jia, R., Ma, Q., Tang, J., et al. (2021). Antagonistic action of Streptomyces pratensis $\mathrm{S} 10$ on Fusarium graminearum and its complete genome sequence. Environ. Microbiol. 23, 1925-1940. doi: 10.1111/1462-2920.15282

Zhang, J., Chen, J., Jia, R. M., Ma, Q., Zong, Z. F., and Wang, Y. (2018b). Suppression of plant wilt diseases by nonpathogenic Fusarium oxysporum Fo47 combined with actinomycete strains. Biocontrol Sci. Tech. 28, 562-573. doi: 10.1080/09583157.2018.1468996

Zhang, H., Yohe, T., Huang, L., Entwistle, S., Wu, P. Z., Yang, Z. L., et al. (2018a). dbCAN2: a meta server for automated carbohydrate-active enzyme annotation. Nucleic Acids Res. 46, W95-W101. doi: 10.1093/nar/gky418

Conflict of Interest: The authors declare that the research was conducted in the absence of any commercial or financial relationships that could be construed as a potential conflict of interest.

Publisher's Note: All claims expressed in this article are solely those of the authors and do not necessarily represent those of their affiliated organizations, or those of the publisher, the editors and the reviewers. Any product that may be evaluated in this article, or claim that may be made by its manufacturer, is not guaranteed or endorsed by the publisher.

Copyright (C) 2021 Chen, Hu, Chen, Jia, Ma and Wang. This is an open-access article distributed under the terms of the Creative Commons Attribution License (CC BY). The use, distribution or reproduction in other forums is permitted, provided the original author(s) and the copyright owner(s) are credited and that the original publication in this journal is cited, in accordance with accepted academic practice. No use, distribution or reproduction is permitted which does not comply with these terms. 